\title{
TEV-3776 Hybrid ZIRCEX Process Demonstration Siting Study
}

\author{
Alison M Conner
}

September 2019

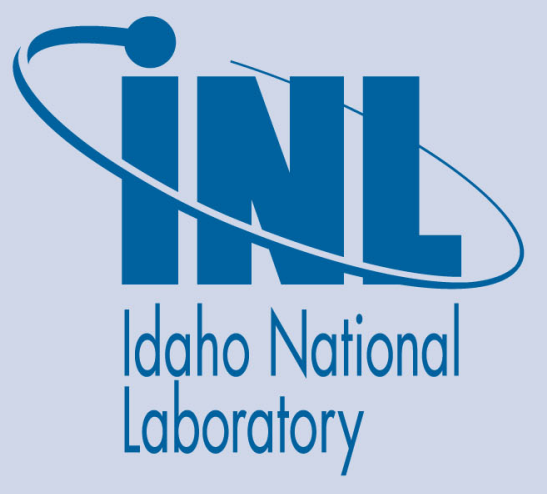

The INL is a U.S. Department of Energy National Laboratory operated by Battelle Energy Alliance 


\title{
TEV-3776 Hybrid ZIRCEX Process Demonstration Siting Study
}

\author{
Alison M Conner \\ September 2019 \\ Idaho National Laboratory \\ Idaho Falls, Idaho 83415 \\ http://www.inl.gov \\ Prepared for the \\ U.S. Department of Energy \\ Under DOE Idaho Operations Office \\ Contract DE-AC07-05ID14517
}


Rev. 05

Title: $\quad$ Hybrid - ZIRCEX Process Demonstration Siting Study

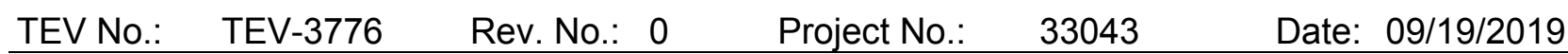

\begin{tabular}{|c|c|c|}
\hline 1. Does this TEV involve a Safety SSC? & No & Professional Engineer's Stamp \\
\hline 2. Safety SSC Determination Document ID & $\mathrm{N} / \mathrm{A}$ & $\begin{array}{c}\text { N/A } \\
\text { See LWP-10010 for requirements. }\end{array}$ \\
\hline 3. Engineering Job (EJ) No. & $\mathrm{N} / \mathrm{A}$ & \\
\hline 4. SSC ID & $\mathrm{N} / \mathrm{A}$ & \\
\hline 5. Building & $\mathrm{N} / \mathrm{A}$ & \\
\hline 6. Site Area & $\begin{array}{l}\text { MFC and } \\
\text { INTEC }\end{array}$ & \\
\hline
\end{tabular}

7. Introduction:

Provide a siting study to locate new buildings associated with the engineering-scale Hybrid - ZIRCEX Process demonstration. This process represents the first-of-a-kind integration of a select group of technologies meant to recover high enriched uranium (HEU) from zirconium and aluminum clad used nuclear fuel (UNF) for down-blending to produce high assay low enriched uranium (HALEU),

8. If revision, please state the reason and list sections and/or pages being affected:

$\mathrm{N} / \mathrm{A}$

9. Conclusions/Recommendations:

Based on this analysis, it is recommended that "Site C - Build New Building East of MFC" be selected as the location for the engineering-scale Hybrid - ZIRCEX Process demonstration. SME input plus cost estimating results indicated and management agreed that as a result of the information currently available, Site $\mathrm{C}$ is the best location.

In addition, completion of the alternative scoring sensitivity analysis demonstrated that when challenged with a $\pm 20 \%$ scoring uncertainty, Site $\mathrm{C}$ clearly remained the higher scoring alternative.

Also recommended is the inclusion of a preliminary vulnerability assessment during the conceptual design phase to determine the full impact of implementing a new program/facility on adjacent existing and future facilities/programs at MFC. 
TEM-10300-1

$12 / 19 / 2017$

Rev. 05

Title: $\quad$ Hybrid - ZIRCEX Process Demonstration Siting Study

$\begin{array}{lllll}\text { TEV No.: } & \text { TEV-3776 Rev. No.: } 0 & \text { Project No.: } 33043 \quad \text { Date: } 09 / 19 / 2019\end{array}$

\section{CONTENTS}

ACRONYMS

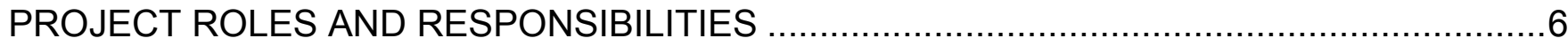

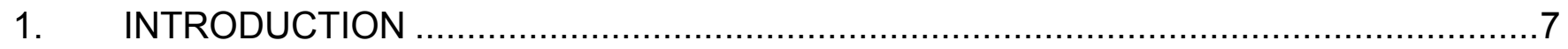

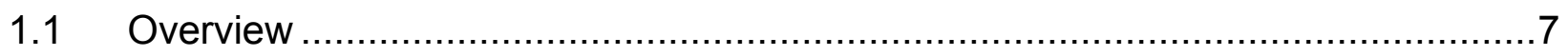

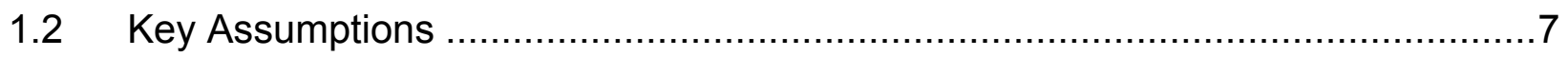

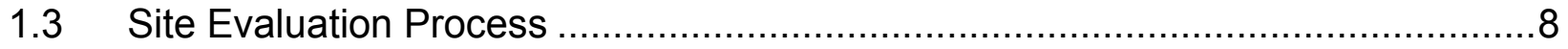

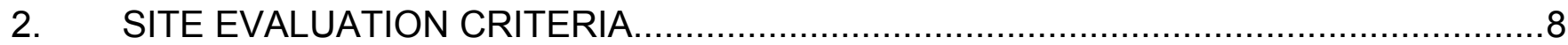

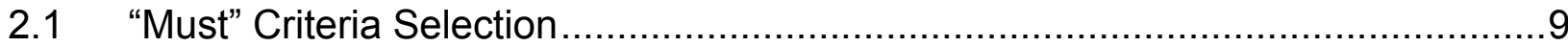

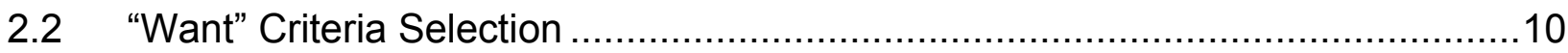

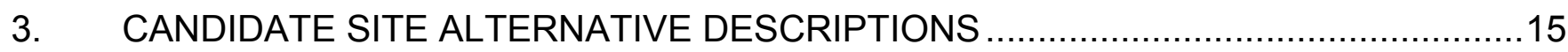

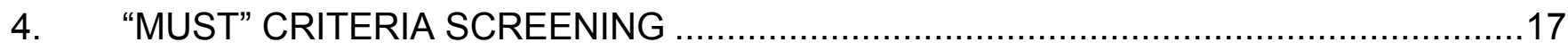

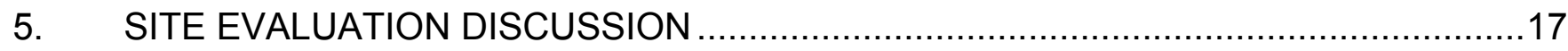

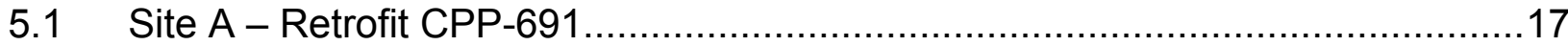

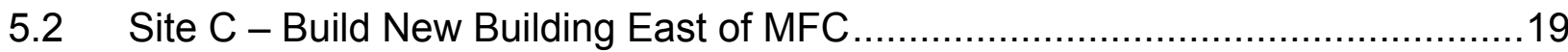

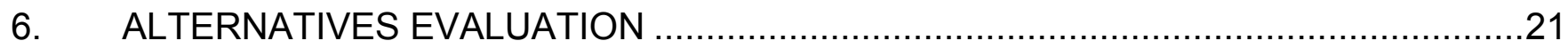

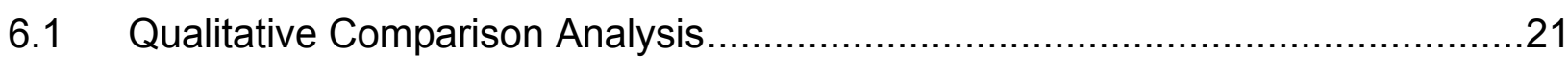

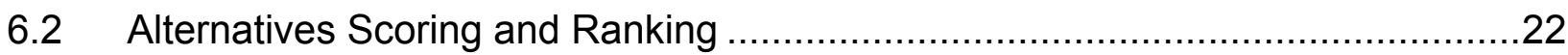

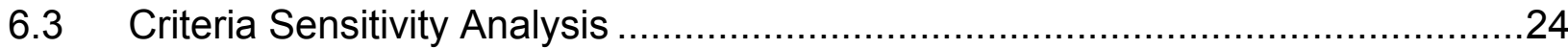

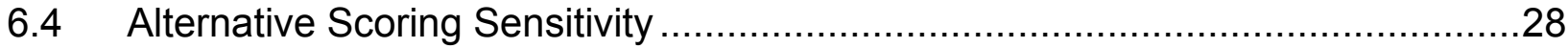

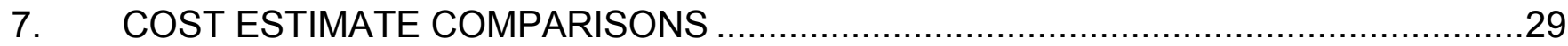

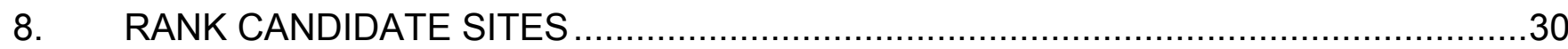

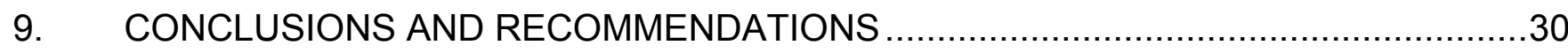

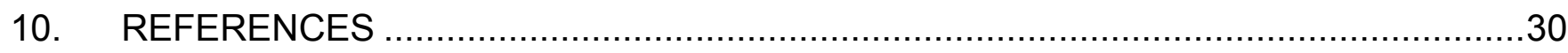

Appendix A - Supporting Hybrid - ZIRCEX Process 60\% Review Sketches....................... A1

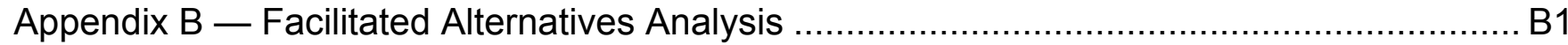

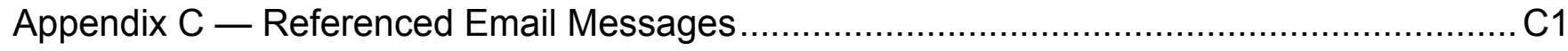

\section{FIGURES}

Figure 1. Haul Road location.

Figure 2. Approximate boundaries of the three distinct microclimate zones of the INL.....................13

Figure 3. Site A location at INTEC.

Figure 4. Siting locations evaluated at MFC. 
TEM-10300-1

$12 / 19 / 2017$

TECHNICAL EVALUATION

Page 3 of 31

Rev. 05

Title: $\quad$ Hybrid - ZIRCEX Process Demonstration Siting Study

$\begin{array}{lllll}\text { TEV No.: } & \text { TEV-3776 Rev. No.: } 0 & \text { Project No.: } 33043 \quad \text { Date: } 09 / 19 / 2019\end{array}$

Figure 5. Hybrid-ZIRCEX siting alternatives scoring results. ................................................23

Figure 6. Criterion contribution to alternative overall weighted utility score ....................................24

Figure 7. Minimize risk of negatively impacting ability to meet demonstration schedule criterion weight sensitivity with transition point identified relative to assigned weight setting....

Figure 8. Ease of fuel element transportation criterion weight sensitivity with assigned weight setting. 25

Figure 9. Minimize potential concerns with chlorine building with respect to collocated workers criterion weight sensitivity with assigned weight setting.

Figure 10. Minimize potential adverse interactions with existing facilities criterion weight sensitivity with assigned weight setting.....

Figure 11. Minimize potential adverse interactions with future facilities criterion weight sensitivity with assigned weight setting.

Figure 12. Ease of constructability criterion weight sensitivity with assigned weight setting. ..............27

Figure 13. Minimize mission impact criterion weight sensitivity with assigned weight setting. .............28

Figure 14. Alternative scoring sensitivity analysis.

\section{TABLES}

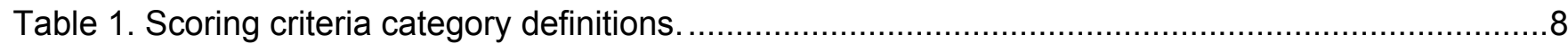

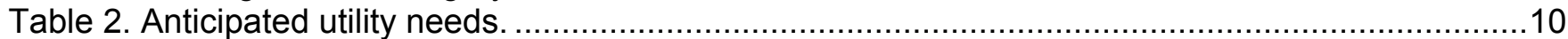

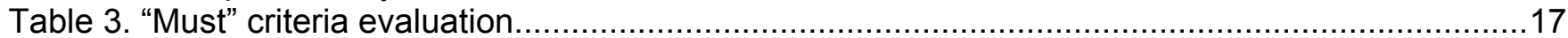

Table 4. Hybrid-ZIRCEX siting selection goals and criteria weights. ............................................22

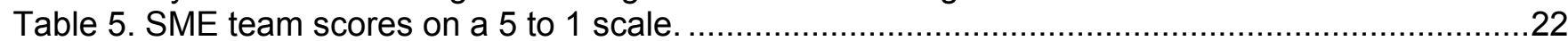

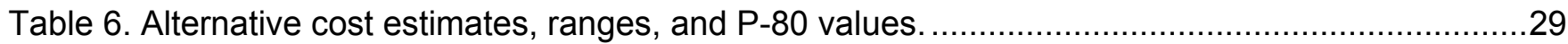

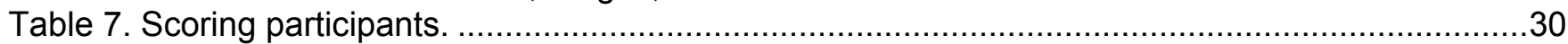


TEM-10300-1

$12 / 19 / 2017$

TECHNICAL EVALUATION

Page 4 of 31

Rev. 05

Title: $\quad$ Hybrid - ZIRCEX Process Demonstration Siting Study

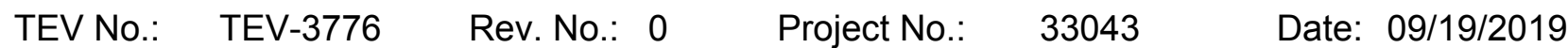

\section{ACRONYMS}

AoA analysis of alternatives

ATR Advanced Test Reactor

CFA Central Facilities Area

$\mathrm{Cl} 2$ chlorine gas

CITRC Critical Infrastructure Test Range Complex

CPP Chemical Processing Plant (formerly ICPP, now INTEC)

DOE Department of Energy

DOE-EM Department of Energy Office of Environmental Management

DOE-NE Department of Energy Office of Nuclear Energy

DOT Department of Transportation

F\&ORs Functional and Operational Requirements

FPF Fuel Processing Facility (FPF) (CPP-691, also referred to as FPR Facility)

FPR Fuel Processing Restoration (project)

HALEU high-assay low-enriched uranium ( $>5 \%$ and $<20 \% 235$ U)

$\mathrm{HCl}$ hydrogen chloride

HEU high-enriched uranium

HLC High-Load Charger (cask)

HURD Hybrid Uranium Recovery Demonstration

INL Idaho National Laboratory

INTEC Idaho Nuclear Technology and Engineering Center (formerly ICPP)

LCC Large Cell Cask

LEU low-enriched uranium (typically, 3\% to 5\% 235U)

MFC Materials and Fuels Complex

MVA Mega Volt Amp

NRC Nuclear Regulatory Commission

NRF Naval Reactors Facility

PIDAS Perimeter Intrusion Detection and Assessment System

PSHA probabilistic seismic hazard analysis

RWMC Radioactive Waste Management Complex

SME subject matter expert

SPO security police officer

SSHAC Senior Seismic Hazard Analysis Committee 
TEM-10300-1

$12 / 19 / 2017$

TECHNICAL EVALUATION

Page 5 of 31

Rev. 05

Title: $\quad$ Hybrid - ZIRCEX Process Demonstration Siting Study

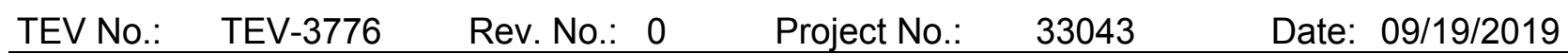

TEV technical evaluation

UNF used nuclear fuel

USGS U.S. Geological Survey

VTR Versatile Test Reactor

ZIRCEX Zirconium Extraction (non-aqueous cladding removal process) 
TEM-10300-1

$12 / 19 / 2017$

TECHNICAL EVALUATION

Page 6 of 31

Rev. 05

Title: $\quad$ Hybrid - ZIRCEX Process Demonstration Siting Study

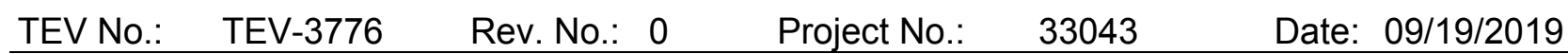

PROJECT ROLES AND RESPONSIBILITIES

\begin{tabular}{|c|c|c|c|}
\hline Project Role & Name (Typed) & Organization & Pages covered (if applicable) \\
\hline Performer & A. Conner & B662 & All \\
\hline Checker $^{\mathrm{a}}$ & L. Guillen, PE & $\mathrm{J} 211$ & All \\
\hline Independent Reviewer ${ }^{\mathrm{b}}$ & $\mathrm{N} / \mathrm{A}$ & & \\
\hline $\begin{array}{l}\text { CUI Reviewer } \\
\text { INL/MIS-19-55623 }\end{array}$ & John T. Major II & M310 & All \\
\hline Manager $^{\mathrm{d}}$ & $\mathrm{N} / \mathrm{A}$ & & \\
\hline Requestor $^{\mathrm{e}}$ & K.J. Perry & F510 & All \\
\hline Nuclear Safety ${ }^{\mathrm{e}}$ & N/A & & \\
\hline Document Owner ${ }^{\mathrm{e}}$ & M.W. Patterson & $\mathrm{C} 400$ & All \\
\hline \multicolumn{4}{|l|}{ Responsibilities } \\
\hline \multicolumn{4}{|c|}{ a. Confirmation of completeness, mathematical accuracy, and correctness of data and appropriateness of assumptions. } \\
\hline \multicolumn{4}{|c|}{ b. Concurrence of method or approach. See definition, LWP-10106. } \\
\hline \multicolumn{4}{|c|}{ c. Concurrence with the document's markings in accordance with LWP-11202. } \\
\hline \multicolumn{4}{|c|}{ d. Concurrence of procedure compliance. Concurrence with method/approach and conclusion. } \\
\hline \multicolumn{4}{|c|}{ e. Concurrence with the document's assumptions and input information. See definition of Acceptance, LWP-10300. } \\
\hline
\end{tabular}

NOTE: Delete or mark "N/A" for project roles not engaged. Include ALL personnel and their roles listed above in the eCR system. The list of the roles above is not all inclusive. If needed, the list can be extended or reduced. 
Rev. 05

Title: $\quad$ Hybrid - ZIRCEX Process Demonstration Siting Study

$\begin{array}{llllll}\text { TEV No.: } & \text { TEV-3776 } & \text { Rev. No.: } & 0 & \text { Project No.: } 33043 \quad \text { Date: } 09 / 19 / 2019\end{array}$

\section{INTRODUCTION}

\subsection{Overview}

The purpose of this technical evaluation (TEV) is to detail the siting considerations for supporting preconceptual design of the engineering-scale Hybrid - ZIRCEX Process (formerly known as Hybrid Uranium Recovery Demonstration [HURD]) demonstration. This process represents the first-of-a-kind integration of a select group of technologies meant to recover high enriched uranium (HEU) from zirconium and aluminum clad used nuclear fuel (UNF) for down-blending to produce high assay low enriched uranium (HALEU).

Based on the results of the analysis of alternatives (AoA) documented in INL/LTD-19-52633, "Study Plan and Final Report: Analysis of Alternatives for Hybrid Uranium Recovery Demonstration Site Selection," the siting locations evaluated in this TEV were drawn from the two highest ranking alternatives from the AoA:

- $\quad$ Build a new facility

- $\quad$ Modify and use CPP-691 (Fuel Reprocessing Restoration Facility).

The functional and operational requirements (F\&ORs) for the Hybrid - ZIRCEX Process demonstration will be defined in a separate document.

\subsection{Key Assumptions}

Specific key assumptions employed during the siting study evaluation include the following:

- $\quad$ The Hybrid - ZIRCEX Process demonstration facility will be designed and implemented as a stand-alone facility, independent of any existing and potential future adjacent facilities (i.e., Versatile Test Reactor [VTR])

- While the approach to providing chlorine $(\mathrm{Cl} 2)$ to the process systems has not been finalized, for the purposes of this study an on-site quantity scenario is assumed with the $\mathrm{Cl} 2$ or hydrogen chloride $(\mathrm{HCl})$ gas supply stored in a 10,000-gallon storage tank, above ground within a new, independent structure. This structure will be located approximately $200 \mathrm{ft}$. away from the primary Hybrid - ZIRCEX Process facility, downwind, in a $30 \mathrm{ft}$. $30 \mathrm{ft}$. building. The building will be a single-story structure with a catch basin and have its own ventilation and scrubber system that would protect workers and the environment in the event of a gas leak. As such, this portion of the process is a non-discriminator for identifying the most suitable location.

- $\quad$ The Hybrid - ZIRCEX Process demonstration facility is envisioned as a multi-level structure that is assumed to have both above and below grade structure. (Patterson et al. 2019)

- $\quad$ Due to the high level of radioactivity, heavy shielding requirements, and extensive safeguards and security requirements, it is assumed that sample preparation and examination activities will be conducted within the new Hybrid - ZIRCEX Process demonstration facility. This will eliminate the need for transporting and transferring ownership (accountability) of the process samples. Therefore, preparation and analysis are a non-discriminator for determining the most suitable location. 
Rev. 05

Title: $\quad$ Hybrid - ZIRCEX Process Demonstration Siting Study

$\begin{array}{llllll}\text { TEV No.: } & \text { TEV-3776 } & \text { Rev. No.: } & 0 & \text { Project No.: } 33043 \quad \text { Date: } 09 / 19 / 2019\end{array}$

- $\quad$ The selected site location will be in an area of adequate size to implement an independent Hybrid - ZIRCEX Process-demonstration-facility-specific Perimeter Intrusion Detection and Assessment System (PIDAS) around the facility and supporting structures with gates to accommodate shipments into the area.

- $\quad$ Designed as a new Hazard Category 2 nuclear facility, this facility shall be designed to cost-effectively comply with all applicable safeguards and security requirements associated with the fuel types, forms, and quantities being processed. (Patterson et al. 2019)

\subsection{Site Evaluation Process}

While a facility site evaluation process considers many detailed and often complex criteria, it can be refined into an efficient five-step process that analyzes available data and information in a logical sequence. As presented here, the process makes extensive use of previous siting studies to take full advantage of criteria development and decision analyses or ranking strategies that have proven successful in the past. The five-step process is as follows:

1. Identify siting criteria (both "Must" and "Want")

2. Identify candidate sites

3. Apply "Must" screening criteria to all candidate sites

4. Evaluate remaining candidate sites against "Want" criteria

5. Rank candidate sites and recommend the most suitable site(s).

The "Must" and "Want" criteria are defined in Table 1.

Table 1. Scoring criteria category definitions.

\begin{tabular}{ll}
\hline \multicolumn{1}{c}{ Criterion } & \multicolumn{1}{c}{ Definition } \\
\hline "Must" & $\begin{array}{l}\text { A critical site characteristic that is stated in measurable terms to recognize when an } \\
\text { alternative does and does not meet the criteria; if not met the location is not } \\
\text { suitable. } \\
\text { An important site characteristic that is desirable and may have varying degrees of } \\
\text { importance. }\end{array}$ \\
\hline
\end{tabular}

\section{SITE EVALUATION CRITERIA}

The evaluation process for this siting study began with a cursory review of previously performed siting studies at INL. Siting Study for the Remote-Handled Low-Level Waste (RHLLW) Disposal Project, INL/EXT-07-12902, Revision 2, is the most recently completed siting study at INL done for a nuclear facility. INL/EXT-70-12902 documented a detailed coherent screening process to organize all applicable regulatory requirements and consideration of key assumptions necessary at the conceptual design phase. The referenced study also included a review of previous siting studies at INL to determine the nature of the facilities for which each study was performed and to analyze the siting criteria that were used in those studies. A review of the outcome of the referenced study and other 
TEM-10300-1

$12 / 19 / 2017$

TECHNICAL EVALUATION

Page 9 of 31

Rev. 05

Title: $\quad$ Hybrid - ZIRCEX Process Demonstration Siting Study

$\begin{array}{lllll}\text { TEV No.: } & \text { TEV-3776 Rev. No.: } 0 & \text { Project No.: } 33043 \quad \text { Date: 09/19/2019 }\end{array}$

previously completed siting studies at INL were scanned for potential applicable evaluation criteria for the Hybrid - ZIRCEX Process demonstration siting study.

\section{1 "Must" Criteria Selection}

The Hybrid - ZIRCEX Process demonstration siting study utilized the output from the criteria screening effort and project specific criteria as a starting point in identifying applicable site evaluation criteria.

Below is the list of "Must" criteria and basis for criteria selection.

"Must" Criteria:

1. Must not be located within $5 \mathrm{mi}$ of a capable fault.

Basis: Minimizing the risk from seismic events is an important consideration and is addressed by the natural phenomena hazards clauses in DOE Order 420.1 and DOE Guide 420.1-1. The Nuclear Regulatory Commission (NRC) definition of a capable fault states in part that a fault is capable if there has been ground movement at or near the ground surface at least once in the past 35,000 years or movement of a recurring nature within the past 500,000 years. Based on this definition, the capable faults nearest to INL are the Howe section of the Lemhi fault, the Arco section of the Lost River fault (U.S. Geological Survey [USGS] 2006), and the Blue Dome segment of the Beaverhead fault. These faults terminate just outside the western border of INL, but if a 5-mi scoring zone is considered, the zones for the Lemhi and Beaverhead faults would extend onto INL. Owing to the potential importance of minimizing risk from seismic events and the relative ease of avoiding sites near capable faults, this "Must" criterion is appropriate, and the 5-mi buffer is understood to be conservative.

2. Must not be in an area of less than 290,000 sq. $\mathrm{ft}$. (6.66 acres)

Basis: Based on the analysis of alternatives study (Patterson et al. 2019), the building is estimated to require a minimum footprint of 25,000 sq. ft. (Guillen 2019).

In addition, the footprint will include the area required for implementing a PIDAS around the building and supporting structure that will house the $\mathrm{Cl} 2$ (or $\mathrm{HCl}$ ) gas supply storage.

The total area needed from the building for a PIDAS is a $60 \mathrm{ft}$. perimeter around the building; $20 \mathrm{ft}$. from the building to the interior fence, $20 \mathrm{ft}$. from the interior fence to the outer fence clear of fabricated or natural objects that would interfere with operation of detections systems or the effectiveness of the assessment, and $20 \mathrm{ft}$. clear beyond the outer fence. The PIDAS surrounding the protected area must be monitored in a continuously manned central alarm station and a secondary alarm station. Also, the fence at a minimum must be $7 \mathrm{ft}$. in height including the razor wire at the top, be of 11-gauge wire mesh with openings no greater than 2 inches. The fence must extend to within 2 inches of hard ground (Heyer 2019).

The third factor contributing to the total area of the facility footprint is the inclusion of the $\mathrm{Cl} 2$ (or $\mathrm{HCl}$ ) gas supply storage tank. Based on the assumption documented in section 2.2, the area surrounding this structure has a radius of $200 \mathrm{ft}$. from any collocated building. 
TEM-10300-1

$12 / 19 / 2017$

TECHNICAL EVALUATION

Page 10 of 31

Rev. 05

Title: $\quad$ Hybrid - ZIRCEX Process Demonstration Siting Study

$\begin{array}{llllll}\text { TEV No.: } & \text { TEV-3776 } & \text { Rev. No.: } & 0 & \text { Project No.: } 33043 \quad \text { Date: } 09 / 19 / 2019\end{array}$

3. Must be located outside wetland areas

Basis: Protection of wetlands is mandated in Executive Order 11990. There is only one jurisdictional wetland defined at the INL Site and it is in the vicinity of the Big Lost River Sinks. Given the high desert environment at INL, mitigation actions required to compensate for location of a facility in a wetland would be difficult, leaving relocation of the facility as the most suitable option. Consequently, avoidance of wetlands is considered a "Must" criterion for the siting evaluation.

4. Must be in an area that can provide the required utilities

Basis: The utility needs of the engineering-scale Hybrid - ZIRCEX Process demonstration are documented in TEV-3777, "Hybrid - ZIRCEX Utility Study," and summarized in Table 2 below.

Table 2. Anticipated utility needs.

\begin{tabular}{|l|l|l|}
\hline \multicolumn{1}{|c|}{ Utility } & \multicolumn{1}{|c|}{ Assumption } & \multicolumn{1}{c|}{ Basis } \\
\hline Electrical power & $\begin{array}{l}\text { 2.5 MVA-3 MVA with 1 MVA- } \\
\text { 1.5 MVA on standby. }\end{array}$ & $\begin{array}{l}\text { 1/4 scale pilot plant power } \\
\text { requirements and typical load } \\
\text { requirements based on estimated } \\
\text { building size }\end{array}$ \\
\hline $\begin{array}{l}\text { Potable water and sanitary } \\
\text { sewer }\end{array}$ & $\begin{array}{l}\text { The potable water and sewer } \\
\text { systems will be sized to } \\
\text { accommodate a total of } \\
\text { 20 people that will work at } \\
\text { the Hybrid - ZIRCEX Process } \\
\text { facility. }\end{array}$ & Estimated. \\
\hline Telecommunication and data & $\begin{array}{l}\text { Two 144 fiber cables will } \\
\text { provide adequate bandwidth. } \\
\text { Some copper will be } \\
\text { provided for alarms. }\end{array}$ & $\begin{array}{l}\text { 48 fibers per building is a } \\
\text { reasonable value. Two 144 fiber } \\
\text { cables will support up to } \\
6 \text { buildings, allowing for future } \\
\text { growth. }\end{array}$ \\
\hline Demineralized water & $\begin{array}{l}\text { Demineralized water may be } \\
\text { used for cleaning and is } \\
\text { assumed to be a negligible } \\
\text { demand on the potable/fire } \\
\text { water system. }\end{array}$ & Estimated. \\
\hline
\end{tabular}

\section{2 "Want" Criteria Selection}

On June 25, 2019, a meeting of subject matter experts (SMEs) was held to identify the applicable site evaluation "Want" criteria for the Hybrid - ZIRCEX Process demonstration facility. The agenda and list of participants for this meeting is included in Appendix A. The objective of this meeting was to identify the criteria that could be used to adequately differentiate the strengths and weaknesses between the siting alternatives. Below is the list of "Want" criteria that were chosen by the team of SMEs and the basis for consideration for each criterion. 
Rev. 05

Title: $\quad$ Hybrid - ZIRCEX Process Demonstration Siting Study

$\begin{array}{llllll}\text { TEV No.: } & \text { TEV-3776 } & \text { Rev. No.: } & 0 & \text { Project No.: } 33043 \quad \text { Date: } 09 / 19 / 2019\end{array}$

"Want" Criteria:

1. Ease of fuel element transportation

Basis: Locating the facility close to existing transportation routes will reduce cost by minimizing new road construction. This criterion includes proximity to main roads and service roads.

Also, road access must be provided that will allow the transport of the loaded cask vehicles. A haul route will be identified or designed that will provide for the passage of anticipated cask transport loads without damaging any existing infrastructure. Damage to existing roadways can be avoided in various ways, including constructing new roads, upgrading existing roads, and limiting vehicle weights to conform to existing roadway load limits. The truck maneuverability, unloading positioning, and drive slopes will also be taken into consideration when determining the haul route alignment. The site area will be large enough to design appropriate road access for transport loads and vehicles. The evaluation should consider distance from the facility to existing haul routes to identify the length of new access roads, if needed, to connect the facility to existing roads. (Harvego et al. 2010)

Transportation of used nuclear fuel (UNF) within INL Site boundaries are classified as "out of commerce" shipments are not subject to Department of Transportation (DOT) requirements. If it is determined necessary to transport UNF on Highway 20, the shipments will be regulated by DOT and incur additional oversight and required road closures during a shipment.

There is the possibility of using the Haul Road that runs almost parallel to Highway 20 that is within the INL Site boundary and connects the Critical Infrastructure Test Range Complex (CITRC) and Materials and Fuels Complex (MFC) to enable the UNF shipped from the proposed feedstock locations to MFC as "out of commerce" shipments. Per IAG-578, "Tenant Use Agreement Between Sitewide Facility Services, Security, and the Haul Road Project," the Haul Road is a single lane gravel road with turnouts beginning $\sim 1.5$ miles north of the intersection of Highway 20 and Taylor Blvd. and extending 12 miles roughly parallel with T-25 to the intersection of Wilson and Jefferson Blvds. at CITRC. The Haul Road is not a common use road at this time and will be barricaded at the MFC and CITRC ends to control use for safety, shipment, security, and maintenance concerns. There are potential limitations on using the road, such as weather conditions, conflicts with use be other programs, load limitations, etc. Also, per EC INL-18-045, "Environmental Checklist for the Haul Road," the road has a design capacity for a 100,000-lb gross vehicle weight, double-droop, three-axle trailer with a 6-inch ground clearance. Shipments not exceeding 80,000 lbs would occur from 2010 to 2050.

Figure 1 depicts the location of the Haul Road. If this Road is unavailable or a proposed shipment exceeds the Haul Road design capacity, the shipment route will have to cross Highway 20, which imposes additional DOT requirements and road closures. The UNF feedstock would have to be shipped a greater distance to this siting location. 
Rev. 05

Title: $\quad$ Hybrid - ZIRCEX Process Demonstration Siting Study

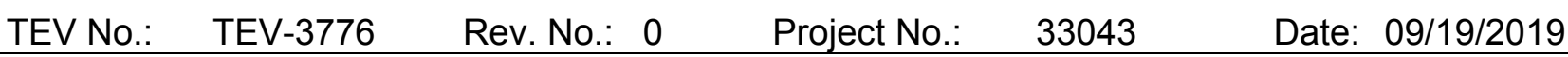

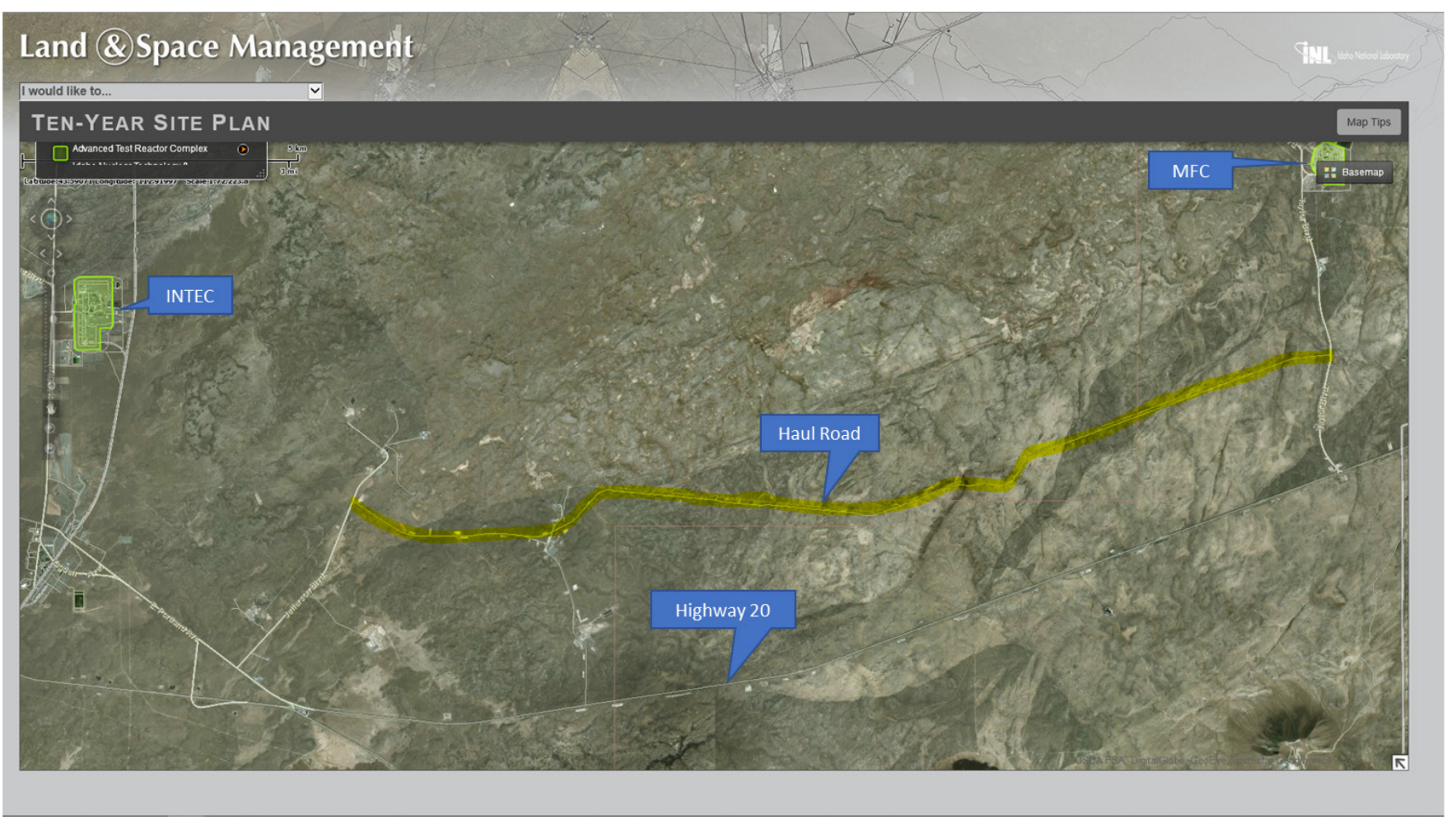

Figure 1. Haul Road location.

2. Minimize potential concerns with chlorine building with respect to collocated workers

Basis: As identified in section 2.2, the bulk $\mathrm{Cl} 2$ (or $\mathrm{HCl}$ ) gas supply will be stored in a 10,000-gallon storage tank, above ground within a new, independent structure. This structure will be located approximately $200 \mathrm{ft}$. away from the primary Hybrid - ZIRCEX Process demonstration facility, downwind, in a $30 \mathrm{ft} . \times 30 \mathrm{ft}$. building. The building will be a single-story structure with a catch basin and have its own ventilation and scrubber system that would protect workers and the environment in the event of a gas leak. The team of SMEs identified this criterion to evaluate the siting alternatives in the event of a significant or catastrophic leak. Aspects covered with this criterion included consideration of potential adjacent workers (current and future, evacuation perimeters [3.6 miles away from leak], potential to effect other INL facility areas, impact of total personnel evacuations, closeness of Highway 20 and the public, etc.

The ability to utilize existing emergency services at the site reduces the potential need to build and maintain a new emergency facility to support the Hybrid - ZIRCEX Process demonstration facility. Locating the facility close to existing emergency services also provides added safety to facility personnel by reducing the response time of emergency services.

The INL Fire Department provides manual fire suppression capability, emergency medical services (EMS), hazardous materials response, and technical rescue services for the INL site facilities. The department response is considered for all potential emergencies involving fire, explosion, electrical, chemical, radiological, and natural disaster events at the INL. 
Rev. 05

Title: $\quad$ Hybrid - ZIRCEX Process Demonstration Siting Study

$\begin{array}{lllll}\text { TEV No.: } & \text { TEV-3776 Rev. No.: } 0 & \text { Project No.: } 33043 \quad \text { Date: } 09 / 19 / 2019\end{array}$

Also, the physiographic features of INL cause three distinct local or micro-climatic zones, depicted in Figure 2. The two INL climate zones that will be considered in this analysis are the Southwest (Advanced Test Reactor [ATR] Complex, Idaho Nuclear Technology and Engineering Center [INTEC], Central Facilities Area [CFA], CITRC, and Radioactive Waste Management Complex [RWMC]) and Southeast (MFC).

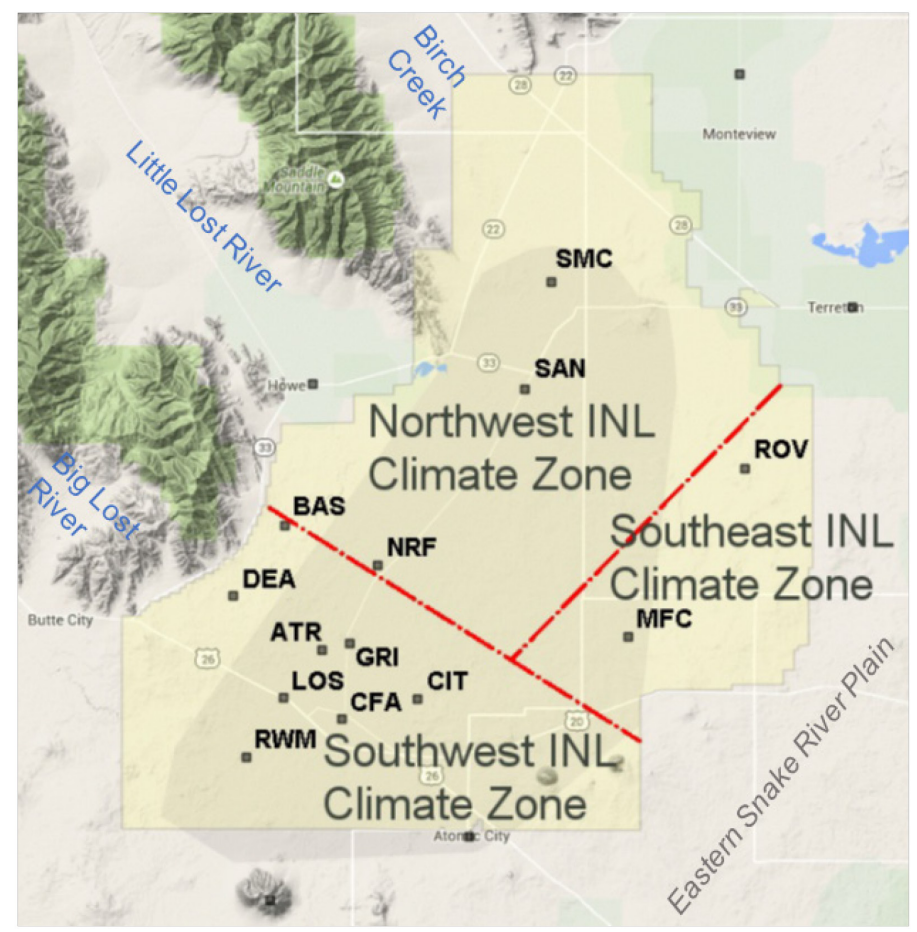

Figure 2. Approximate boundaries of the three distinct microclimate zones of the INL.

The southwest portion of INL is commonly influenced by shallow nighttime down-valley winds that are associated with the Big Lost River channel from CFA to INTEC. This area is also influenced by strong pre-frontal southwesterly winds and frequent afternoon winds, also from the southwest, that result from the daytime heating cycle.

The southeast portion of INL is isolated from the channeling flows that commonly affect the western portions of the site. In that area, air temperatures, cloud cover, and surface winds are influenced by the subtle features of topography and higher elevation along the southern perimeter of the INL (Clawson et al. 2018).

3. Minimize potential adverse interactions with existing facilities and programs

Basis: Considerations of this criterion include potential impact of displacing or impacting operations of collated or adjacent existing projects and programs. INTEC and MFC have programs that are currently in operation and will exist for many years. 
Rev. 05

Title: $\quad$ Hybrid - ZIRCEX Process Demonstration Siting Study

TEV No.: $\quad$ TEV-3776 Rev. No.: $0 \quad$ Project No.: $33043 \quad$ Date: 09/19/2019

Regarding security impacts on existing programs, the location of the facility should not be a discriminating siting factor, whenever a new facility is stood up, an assessment will be conducted to determine what detection systems or number of security police officers (SPOs) are needed to comply with regulations (Beebe 2019).

4. Minimize potential adverse interactions with future facilities and programs

Basis: Considerations of this criterion include potential impact of displacing or impacting operations of collated or adjacently planned future projects and programs. At this time, no new programs are planned at INTEC. The Versatile Test Reactor (VTR) is currently being planned and anticipated to be in the south east corner of MFC.

5. Minimize risk of negatively impacting ability to meet demonstration schedule

Basis: The preferred alternative will minimize the risk of meeting the current planning schedule of completing Demonstration construction in 2023 and initiating hot operations in 2025.

6. Ease of constructability

Basis: Site locations that may provide for efficient, cost-effective; and safe construction access should be considered as follows:

- $\quad$ Security thoroughfare efficiency

- $\quad$ Construction perimeter around building.

- $\quad$ Accessibility to existing utilities

Also, the Hybrid - ZIRCEX Process demonstration facility will require major components to be delivered to the construction site. Locating the facility near an existing transportation route, including main roads and rail lines, service roads, would provide ease of delivery of construction materials and reduce construction costs by minimizing the need for potential new roads. Consideration should also include modifying existing structures, moving fences, and inherent liabilities associated with modifying existing buildings.

Because the facility will be a Hazard Category 2 nuclear facility power distribution reliability and availability are an important concern. Having a primary and secondary selective configuration minimizes single points of failure and gives maximum flexibility for maintaining normal power operation during planned and unplanned outages.

7. Minimize mission impact (DOE-EM v. DOE-NE, agreements, competing missions, mission delay concerns)

Basis: Impacts on current program missions are a significant concern in identifying the ideal location of Hybrid - ZIRCEX Process demonstration. Consideration of impact needs to include minimizing or preventing operation delays on potentially competing missions within a specific facility area, interagency agreement requirements, cost sharing implications, etc. Currently, INTEC is managed and operated by the Department of Energy Office of Environmental 
Rev. 05

Title: $\quad$ Hybrid - ZIRCEX Process Demonstration Siting Study

$\begin{array}{lllll}\text { TEV No.: } & \text { TEV-3776 } & \text { Rev. No.: } 0 & \text { Project No.: } 33043 \quad \text { Date: } 09 / 19 / 2019\end{array}$

Management (DOE-EM) and MFC is managed and operated by the Office of Nuclear Energy (DOE-NE).

\section{CANDIDATE SITE ALTERNATIVE DESCRIPTIONS}

Based on the results of the Hybrid - ZIRCEX Process site selection AoA, this siting study was asked to evaluate four possible locations, one at INTEC and three at MFC.

Site A - Retrofit CPP-691: This candidate siting area is located at INTEC and proposes to use a portion of the shielded cells located in the unfinished CPP-691 (a.k.a., Fuel Processing Restoration Project Facility [FPR]) with newly installed infrastructure support systems to complete the building and make it operational. Figure 3 illustrates the location of Site A at INTEC.

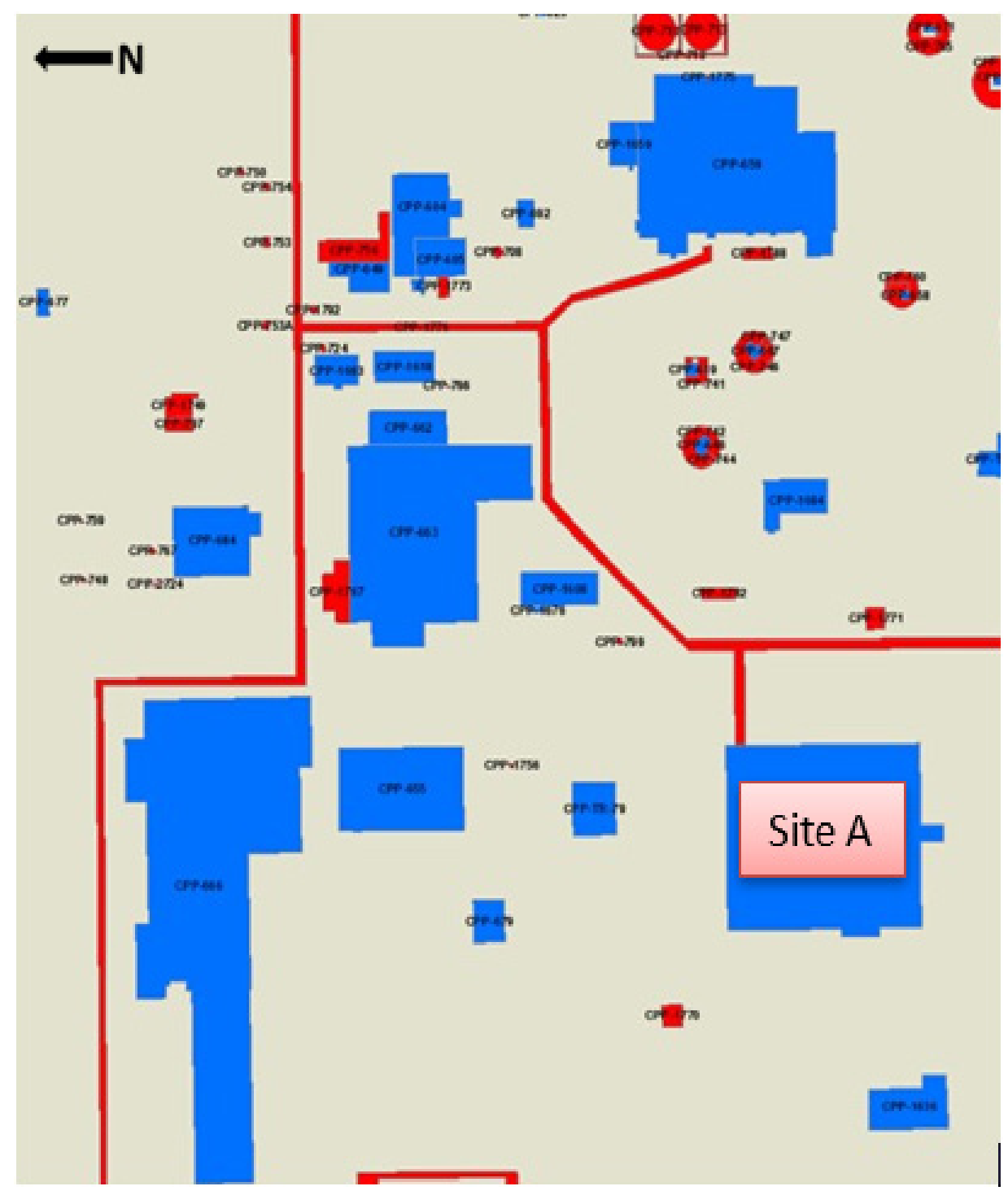

Figure 3. Site A location at INTEC. 
Rev. 05

Title: $\quad$ Hybrid - ZIRCEX Process Demonstration Siting Study

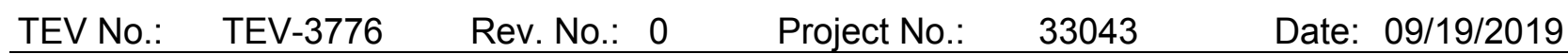

The three potential locations at MFC that were evaluated included the following:

- $\quad$ Site B - Build new building in southeast corner of MFC: This candidate siting area is located just outside of the existing security fence of MFC and directly adjacent to the proposed VTR project

- $\quad$ Site C - Build new building east of MFC: This candidate siting area is located outside of the existing security fence of MFC

- $\quad$ Site D - Build new building within footprint of MFC-753: This candidate siting area proposes to build within the footprint of the existing MFC-753, "Plant Services Building."

Figure 4 illustrates the candidate siting alternatives at MFC.

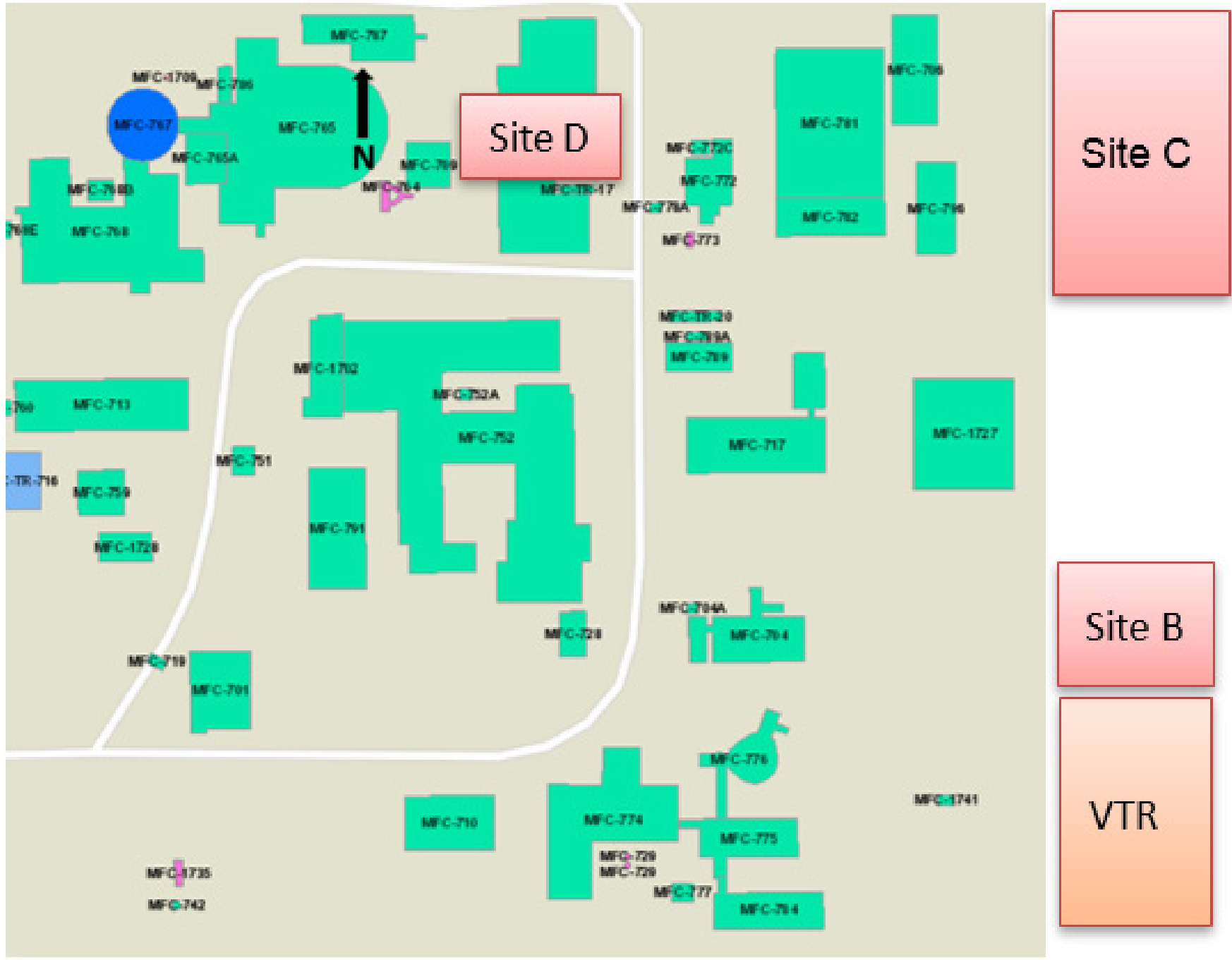

Figure 4. Siting locations evaluated at MFC. 
TEM-10300-1

$12 / 19 / 2017$

TECHNICAL EVALUATION

Page 17 of 31

Rev. 05

Title: $\quad$ Hybrid - ZIRCEX Process Demonstration Siting Study

$\begin{array}{llllll}\text { TEV No.: } & \text { TEV-3776 } & \text { Rev. No.: } & 0 & \text { Project No.: } 33043 \quad \text { Date: } 09 / 19 / 2019\end{array}$

\section{4. "MUST" CRITERIA SCREENING}

The third step in the evaluation process requires that each of the candidate sites be evaluated against the five "Must" criteria. Two of the four sites failed the siting study "Must" criteria evaluation (as shown in Table 3).

Table 3. "Must" criteria evaluation.

\begin{tabular}{|c|c|c|c|c|c|}
\hline \multirow[b]{2}{*}{ Site } & \multirow[b]{2}{*}{ Location } & \multicolumn{4}{|c|}{$\begin{array}{c}\text { Criteria } \\
(\mathrm{P}=\mathrm{Pass}, \mathrm{F}=\text { Fail })\end{array}$} \\
\hline & & 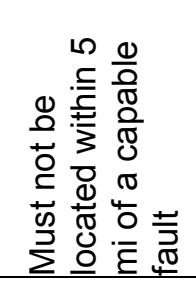 & 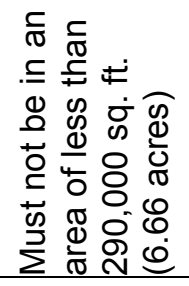 & 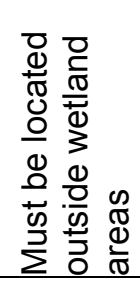 & 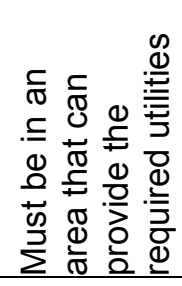 \\
\hline A & Retrofit CPP-691 & $\mathrm{P}$ & $\mathrm{P}$ & $\mathrm{P}$ & $\mathrm{P}$ \\
\hline B & $\begin{array}{l}\text { Build new building in southeast corner of MFC, } \\
\text { adjacent to VTR }\end{array}$ & $\mathrm{P}$ & $\mathrm{F}$ & $\mathrm{P}$ & $\mathrm{P}$ \\
\hline $\mathrm{C}$ & $\begin{array}{l}\text { Build new building east of MFC outside of the } \\
\text { existing security fence }\end{array}$ & $\mathrm{P}$ & $\mathrm{P}$ & $\mathrm{P}$ & $\mathrm{P}$ \\
\hline $\mathrm{D}$ & Build new building within footprint of MFC-753 & $\mathrm{P}$ & $\mathrm{F}$ & $\mathrm{P}$ & $\mathrm{P}$ \\
\hline
\end{tabular}

Of the two sites that failed the "Must" criteria evaluation, they both failed the "Must not be in an area of less than 290,000 sq. ft. (6.66 acres)" criterion.

Basis for Site B failure determination: Based on the proposed location of the VTR project and the location of the existing operational buildings to the east of Site $B$, this location does not provide adequate space to implement the requirements for a Hybrid - ZIRCEX Process demonstration facility specific PIDAS and area required for the supporting bulk chemical storage tank.

Basis for Site D failure determination: MFC-753 has an external footprint of 23,300 sq. ft. In addition, MFC-TR-17, Electric Equipment Storage Trailer, covering 346 sq. $\mathrm{ft}$. is included at the site location. Footprint of the two buildings totals approximately 23,700 sq. $\mathrm{ft}$. This building is in the center of MFC surrounded on all four sides by existing operational buildings and roadways. This location does not provide adequate space to meet the maximum area requirement of $290,000 \mathrm{sq} . \mathrm{ft}$.

Detailed illustrations of the two remaining sites, Site A and Site C, are provide as sketches in Appendix A.

\section{SITE EVALUATION DISCUSSION}

\subsection{Site A - Retrofit CPP-691}

1. Ease of fuel element transportation

There is an existing partial paved, partial gravel road up to CPP-691. Roadway improvements will be required. For future reference if needed, there are railroad tracks adjacent to the building to the east. 
Rev. 05

Title: $\quad$ Hybrid - ZIRCEX Process Demonstration Siting Study

TEV No.: $\quad$ TEV-3776 Rev. No.: $0 \quad$ Project No.: $33043 \quad$ Date: 09/19/2019

Based on historical operations at INTEC, it would be easier to get UNF in and out at this location due to a previously established UNF shipping route. There is adequate space for a truck to pull into and out of the area. It is the closer alternative to the proposed UNF feedstock locations.

2. Minimize potential concerns with chlorine building with respect to collocated workers

This siting alternative has adequate space to locate the chlorine building downwind and at the required distance from adjacent buildings. Due to INTEC's lower population and security posture, impacts of a total evacuation of all personnel would be less of an impact at INTEC. With a significant leak, the required evacuation perimeter is up to 3.6 miles from the release. This has the potential to impact the Central Facilities Area (CFA), Advanced Test Reactor (ATR) Complex, and Naval Reactors Facility (NRF).

If emergency response personnel are needed at the facility, Fire Station No. 1 is located at the Central Facilities Area (CFA), approximately 3 miles from INTEC.

3. Minimize potential adverse interactions with existing facilities and programs

The Calcine Disposition Project's retrieval demonstration in full size, using temporary calcine retrieval equipment is mocked up in CPP-691. This effort is funded by DOE-EM and has equipment installed in Cell 7 , piping runs through parts of the facility, and other equipment staged on cell hatches. There is no clear timeframe for the completion of the work, but it is only using a portion of the facility. The equipment could be removed, with minimal programmatic impact, if higher priority needs were identified for the building. (Patterson et al. 2019)

The full impact on existing facilities and programs that would be realized if this location is selected will be identified in the completion of a formal vulnerability assessment. Identified concerns that will be addressed by a vulnerability assessment include the following:

- $\quad$ Security infrastructure upgrades that will be needed to locate the demonstration at this site

- Determination of the potential to change the security posture of adjacent buildings

- Identification of potential security impacts and Design Basis Threat (DBT) of radiological and chemical storage sabotage concerns imposed by the 10,000 gal. chlorine storage tank.

4. Minimize potential adverse interactions with future facilities and programs

There are no plans to introduce new facilities or programs at INTEC currently.

5. Minimize risk of negatively impacting ability to meet demonstration schedule

There are typically more unknowns when modifying an existing building. A current unknow that could potentially have a significant impact on meeting the demonstration schedule are the unknown modifications needed to upgrade the building to meet seismic requirements. 
Rev. 05

Title: $\quad$ Hybrid - ZIRCEX Process Demonstration Siting Study

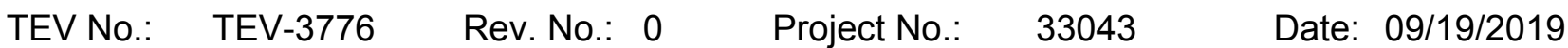

The INL Site-wide Senior Seismic Hazard Analysis Committee (SSHAC) Level 3 probabilistic seismic hazard analyses (PSHA) is currently underway and is anticipated to be completed in July 2021. The study will include INTEC as one of the five sites being evaluated. The Hybrid ZIRCEX Process demonstration should consider the potential costs savings of performing only one seismic structural analysis of CPP-691 using results of the INL Site-wide SSHAC Level 3 study, if the project schedule can support the July 2021 completion date (INL, 2019a).

6. Ease of constructability

CPP-691 currently resides outside the INTEC perimeter security fence. This location will increase the efficiency of security thoroughfare of getting construction subcontractors in and out of the area. There is currently a road up to the building and no anticipated need for demolition of collocated structures.

No significant excavation is needed. The concrete is already in place. Besides the potential seismic modifications required, the remodel is not expected to be as challenging as a typical one due to the minimal amount of equipment that will need to be torn out.

There are inherent liabilities that reside with modification of an existing building. This may limit the number of subcontractors willing to complete the project.

Per the TEV-3777, "Hybrid - ZIRCEX Process Utilities Study," all options to implement the required utilities in CPP-691 will require upgrades of the low voltage distribution system. Reuse of the existing equipment will probably not be cost effective. The pre-conceptual option chosen for upgrading the utilities that is consistent with the current philosophy at INTEC is to upgrade the medium voltage distribution system for a loop feed (primary and secondary selective). A new dual ended 3 MVA transformer for normal operations and a 1.5 MVA diesel generator for standby power will need to be installed exterior to the facility. The existing diesel generator will be abandoned in place. Water and sewer lines currently exist, up to the exterior of the building.

7. Minimize mission impact (DOE-EM v. DOE-NE, agreements, competing missions, mission delay concerns)

Since INTEC is currently under the DOE-EM mission and the Hybrid - ZIRCEX Process demonstration is a DOE-NE program, selection of this siting alternative will require the need for an interagency agreement that presents potential challenges and cost sharing implications for management and operation of INTEC facilities.

\subsection{Site C - Build New Building East of MFC}

1. Ease of fuel element transportation

The MFC Complex has an existing roadway system that consists of paved, gravel, and dirt surfaces. These roadways provide access to buildings and other facilities within and around the MFC Complex. They also offer security access within and surrounding the complex. Each roadway structural section varies throughout the MFC Complex. 
TEM-10300-1

$12 / 19 / 2017$

TECHNICAL EVALUATION

Page 20 of 31

Rev. 05

Title: $\quad$ Hybrid - ZIRCEX Process Demonstration Siting Study

TEV No.: $\quad$ TEV-3776 Rev. No.: $0 \quad$ Project No.: $33043 \quad$ Date: $09 / 19 / 2019$

Due to the proposed location of the Hybrid - ZIRCEX Process demonstration facility, as well as security fence rerouting requirements for this location, roadway improvements will be required.

A perimeter road will follow along the outside portion of the new perimeter fence and tie into the existing roadway system.

The current design capacity of the Haul Road could potentially allow for the transport of an HLC across the Haul Road, but not an LCC.

2. Minimize potential concerns with chlorine building with respect to collocated workers

This siting alternative has adequate space to locate the chlorine building downwind from collocated workers and at the required distance from the Hybrid - ZIRCEX Process building. In this location, there are no closely collocated buildings. MFC is more heavily populated than INTEC and would have greater impacts to operations if a total evacuation of all personnel, including security, is necessary. There may be a fuel storage concern.

MFC has its own security, fire, and emergency response operations for quick response times. The medical facility is located south of the southeast corner MFC-752 in building MFC-728. The MFC Fire Station No. 2 is located on the south side of the complex.

3. Minimize potential adverse interactions with existing facilities and programs

Locating the Hybrid - ZIRCEX Process demonstration at Site $C$ will not require displacement of existing personnel and programs.

The full impact on existing facilities and programs that would be realized if this location is selected will be identified in the completion of a formal vulnerability assessment. Identified concerns that will be addressed by a vulnerability assessment include the following:

- $\quad$ Security infrastructure upgrades that will be needed to locate the demonstration at this site

- Determination of the potential to change the security posture of adjacent buildings

- Identification of potential security impacts and Design Basis Threat (DBT) of radiological and chemical storage sabotage concerns imposed by the 10,000 gal. chlorine storage tank.

4. Minimize potential adverse interactions with future facilities and programs

Coordination with the future VTR construction project will aid in minimizing adverse interactions with this planned facility.

The full impact on future facilities and programs that would be realized if this location is selected will be identified in the completion of a formal vulnerability assessment. 
TEM-10300-1

$12 / 19 / 2017$

TECHNICAL EVALUATION

Page 21 of 31

Rev. 05

Title: $\quad$ Hybrid - ZIRCEX Process Demonstration Siting Study

TEV No.: $\quad$ TEV-3776 Rev. No.: $0 \quad$ Project No.: $33043 \quad$ Date: 09/19/2019

5. Minimize risk of negatively impacting ability to meet demonstration schedule

There is typically less schedule risk with building a new facility, fewer unknowns and fewer security concerns. Since the Site $\mathrm{C}$ is in previously undisturbed ground, there is a risk of uncovering cultural or archaeological artifacts during excavation. If this happens, there will be cost impacts and, possibly, schedule delays while further surveys are conducted, or a path forward is decided upon (Patterson et al. 2019).

6. Ease of constructability

This siting alternative is also proposed to be built outside the existing security fence of MFC. By enabling this, an increase in the efficiency of security thoroughfare of getting construction subcontractors in and out of the area can be realized. There is currently a service road around the perimeter of MFC.

MFC is located adjacent to Highway 20 providing for a shorter commute for construction subcontractors and materials.

Per TEV-3777, utilizing the existing MFC medium voltage distribution system will require some load accounting to ensure the system does not become overloaded. The pre-conceptual option chosen for bringing all required utilities to the new facility that is consistent with the current philosophy at MFC is to install a dual ended loop feed distribution system with primary and secondary selection and a standby, facility-specific 1 MVA diesel generator outside the facility on a pad. All utilities will be new installations since no utility lines currently exist on the westside of MFC. This will require extending the utility corridor from the north of MFC down along the east side of MFC to the Hybrid - ZIRCEX Process demonstration facility.

Significant excavation is expected at this location. The proposed location of the Hybrid ZIRCEX Process demonstration facility may be underlain by a thin veneer of surface soils overlying basalt bedrock with a top layer composed of basalt rubble (INL, 2019b).

7. Minimize mission impact (DOE-EM v. DOE-NE, agreements, competing missions, mission delay concerns)

Since MFC is managed and operated under the DOE-NE mission and the Hybrid - ZIRCEX Process demonstration is a DOE-NE program, then all the programs would be in the same DOE program.

\section{ALTERNATIVES EVALUATION}

\subsection{Qualitative Comparison Analysis}

The Hybrid-ZIRCEX project team completed the evaluation of the alternatives by performing a weighted analysis of the alternatives using the criteria described above. The team initiated the evaluation by conducting a facilitated comparison analysis meeting on June 25,2019 , to evaluate the candidate siting areas against the "Want" criteria and capture input from subject matter experts (SMEs) on how well each alternative performed against the criteria. Appendix B includes the agenda, list of SME participants and matrix of discussion points on how the alternatives performed against the criteria based on SME input. 
Rev. 05

Title: $\quad$ Hybrid - ZIRCEX Process Demonstration Siting Study

$\begin{array}{lllll}\text { TEV No.: } & \text { TEV-3776 Rev. No.: } 0 & \text { Project No.: } 33043 \quad \text { Date: 09/19/2019 }\end{array}$

\subsection{Alternatives Scoring and Ranking}

The Hybrid-ZIRCEX project team utilized the QuickCompare ${ }^{\circledR}$ tool, a tool developed at Idaho National Laboratory (INL) that automates parts of the evaluation, to calculate the total scores of the alternative. The raw qualitative results from Section 7.1, and criteria weighting based on management input were entered in the tool. Within QuickCompare ${ }^{\circledR}$, criteria input scores were converted to utility values for rollup of weighted utility scores to calculate an overall score for each alternative. Table 4 shows the selection goals, associated criteria, and weights used in the analysis. Note that the sum of the weights will add up to $100 \%$ at both the goal and criterion levels. Summing the weights for criteria under a goal will total to the assigned goal weight.

Table 4. Hybrid-ZIRCEX siting selection goals and criteria weights.

\begin{tabular}{|c|c|c|c|c|c|c|c|}
\hline $\begin{array}{r}\text { Goal } \\
\text { Number }\end{array}$ & Goal Name & $\begin{array}{l}\text { Goal Weight } \\
\text { Factor }\end{array}$ & $\begin{array}{r}\text { Criteria } \\
\text { Number }\end{array}$ & Criteria Name & $\begin{array}{l}\text { Criteria Weight } \\
\text { Factor } \\
\text { (within each goal) }\end{array}$ & \begin{tabular}{|l|} 
Associated \\
Goal \\
Number \\
\end{tabular} & $\begin{array}{l}\text { Criteria } \\
\text { Weights } \\
(\%)\end{array}$ \\
\hline 1 & Schedule Effectiveness & 20 & 1 & $\begin{array}{l}\text { Minimize risk of negatively } \\
\text { impacting ability to meet } \\
\text { demonstration schedule }\end{array}$ & 100 & 1 & 20 \\
\hline \multirow[t]{6}{*}{2} & Modifying Factors & 80 & 2 & Ease of fuel element transportation & 15 & 2 & 12 \\
\hline & & & & $\begin{array}{l}\text { Minimize potential concerns with } \\
\text { chlorine building with respect to } \\
\text { collocated workers }\end{array}$ & 15 & 2 & 12 \\
\hline & & & 4 & $\begin{array}{l}\text { Minimize potential adverse } \\
\text { interactions with existing facilities }\end{array}$ & 5 & 2 & 4 \\
\hline & & & & $\begin{array}{l}\text { Minimize potential adverse } \\
\text { interactions with future facilities }\end{array}$ & 30 & 2 & 24 \\
\hline & & & 6 & Ease of constructability & 20 & 2 & 16 \\
\hline & & & 7 & Minimize mission impact & 15 & 2 & 12 \\
\hline
\end{tabular}

The QuickCompare ${ }^{\circledR}$ tool uses a 5 to 1 scale to evaluate how well alternatives perform against criteria. Since the SME team used a 10 to 1 scale during the comparison analysis, those scores were converted to a 5 to 1 scale (see Table 5 ) as defined below:

$5=$ Meets criteria with minimal to no difficulty

$3=$ Meets criteria with some difficulty

$1=$ High degree of uncertainty as to whether the alternative can meet criteria.

Table 5. SME team scores on a 5 to 1 scale.

\begin{tabular}{|l|c|c|}
\hline \multicolumn{1}{|c|}{ Criteria } & $\begin{array}{c}\text { Site A - Retrofit } \\
\text { CPP-691 }\end{array}$ & $\begin{array}{c}\text { Site C - Build New } \\
\text { Building East of MFC }\end{array}$ \\
\hline $\begin{array}{l}\text { Minimize risk of negatively impacting ability to meet } \\
\text { demonstration schedule }\end{array}$ & 5 & 3 \\
\hline Ease of fuel element transportation & 3 & 3 \\
\hline $\begin{array}{l}\text { Minimize potential concerns with chlorine building with } \\
\text { respect to collocated workers }\end{array}$ & 3 & 3 \\
\hline $\begin{array}{l}\text { Minimize potential adverse interactions with existing } \\
\text { facilities }\end{array}$ & 3 & 3 \\
\hline
\end{tabular}


TEM-10300-1

$12 / 19 / 2017$

TECHNICAL EVALUATION

Page 23 of 31

Rev. 05

Title: $\quad$ Hybrid - ZIRCEX Process Demonstration Siting Study

$\begin{array}{llllll}\text { TEV No.: } & \text { TEV-3776 } & \text { Rev. No.: } & 0 & \text { Project No.: } & 33043 \quad \text { Date: } 09 / 19 / 2019\end{array}$

\begin{tabular}{|l|c|c|}
\hline \multicolumn{1}{|c|}{ Criteria } & $\begin{array}{c}\text { Site A - Retrofit } \\
\text { CPP-691 }\end{array}$ & $\begin{array}{c}\text { Site C - Build New } \\
\text { Building East of MFC }\end{array}$ \\
\hline $\begin{array}{l}\text { Minimize potential adverse interactions with future } \\
\text { facilities }\end{array}$ & 3 & 5 \\
\hline Ease of constructability & 3 & 5 \\
\hline Minimize mission impact & 3 & 5 \\
\hline
\end{tabular}

Figure 5 shows the results of the criteria scoring. The bar chart indicates that Site $\mathrm{C}-$ Build New Building East of MFC as the top scoring alternative.

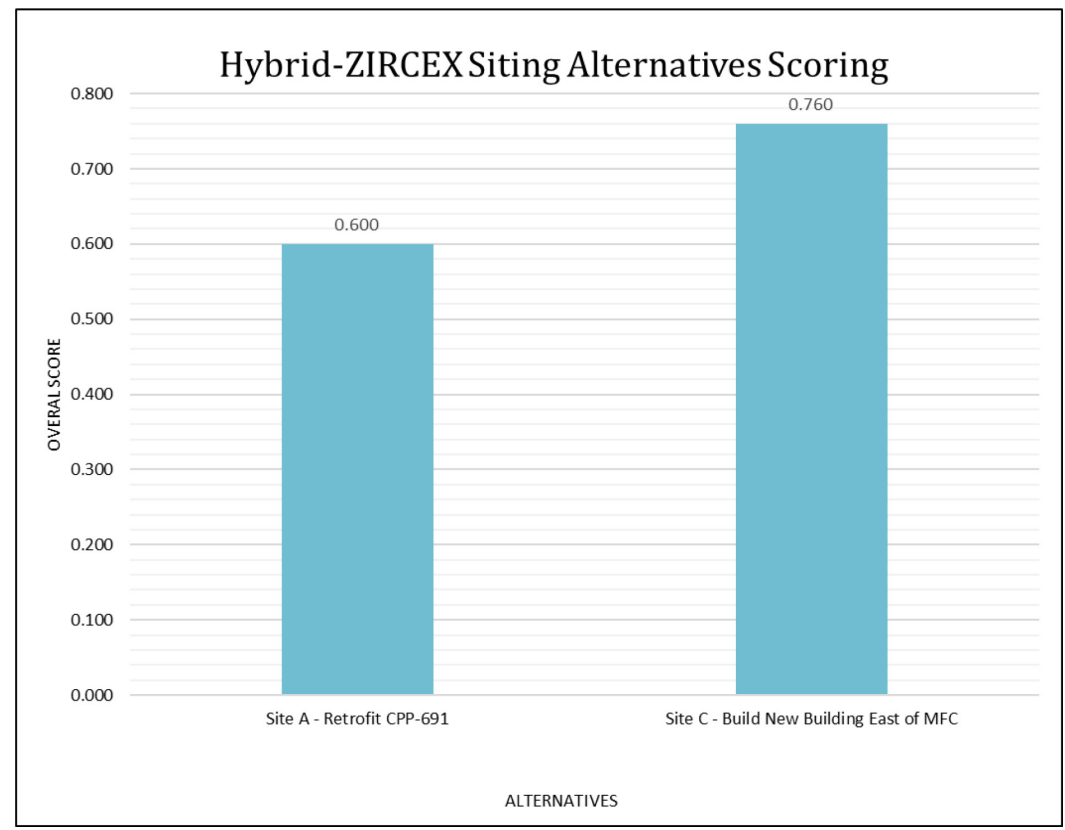

Figure 5. Hybrid-ZIRCEX siting alternatives scoring results.

Figure 6 shows a breakdown of each alternative's overall score illustrating the amount of contribution from each criterion. 
Rev. 05

Title: $\quad$ Hybrid - ZIRCEX Process Demonstration Siting Study

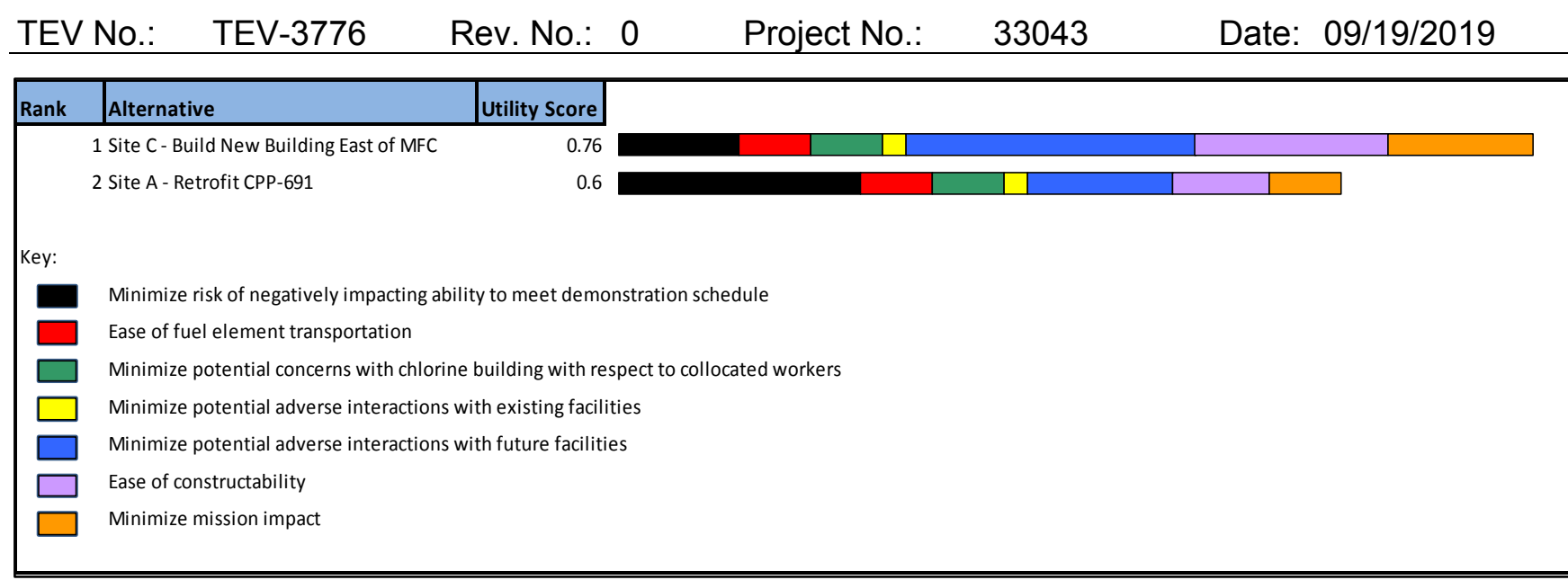

Figure 6. Criterion contribution to alternative overall weighted utility score.

\subsection{Criteria Sensitivity Analysis}

The criteria weighting sensitivity analysis was performed by parametrically varying (in $5 \%$ increments) each criterion weight, one-at-a-time, from 0 to $100 \%$. When the criterion being analyzed carried less than $100 \%$ of the total weight, the other criteria are allocated the remaining weight proportional to their originally assigned weight values. The overall alternative scores were recalculated for each incremental change and charted so that changes in the highest scoring alternative could be easily identified. The following charts show the results of the parametric criteria weighting sensitivity analysis.

Figure 7 shows that the top scoring alternative (i.e., Site $\mathrm{C}-$ Build New Building East of MFC) is somewhat sensitive to "Minimize risk of negatively impacting ability to meet demonstration schedule" criterion weighting uncertainties/errors. The established weight $(20 \%)$ would require about a $20 \%$ upward adjustment before the other alternative (in this case Site A - Retrofit CPP-691) becomes the top scoring alternative. As discussed in the Hybrid - ZIRCEX Process site selection AoA, there is the potential to improve the schedule by six months if Site A were selected due to most of the excavation and concrete pours are complete at this location. Upon further investigation after that AoA was completed, additional concerns were identified that could eliminate that six-month improvement in the schedule include unknowns regarding the seismic analysis, potentially required security upgrades and safety basis upgrades and availability of construction resources willing to modify an existing building. Due to these concerns, adjustment of the weight of this criterion is not warranted. 
TEM-10300-1

$12 / 19 / 2017$

TECHNICAL EVALUATION

Page 25 of 31

Rev. 05

Title: $\quad$ Hybrid - ZIRCEX Process Demonstration Siting Study

$\begin{array}{lllll}\text { TEV No.: } & \text { TEV-3776 Rev. No.: } 0 & \text { Project No.: } 33043 \quad \text { Date: 09/19/2019 }\end{array}$

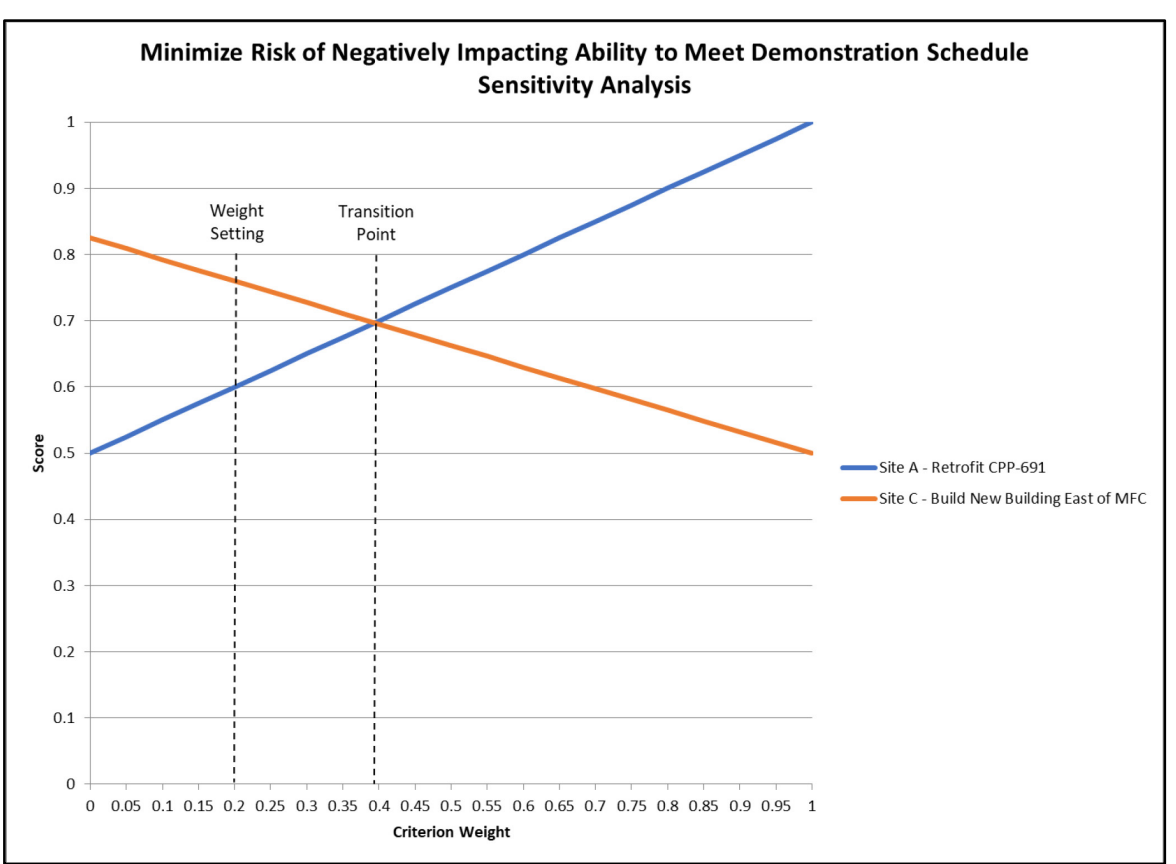

Figure 7. Minimize risk of negatively impacting ability to meet demonstration schedule criterion weight sensitivity with transition point identified relative to assigned weight setting.

Figure 8-Figure 13 illustrate that the top scoring alternative (i.e., Site $\mathrm{C}$ - Build New Building East of MFC) is completely insensitive to the remaining criteria weighting uncertainties/errors. There is no change that can be made to the established weights that results in Site A becoming the top scoring alternative.

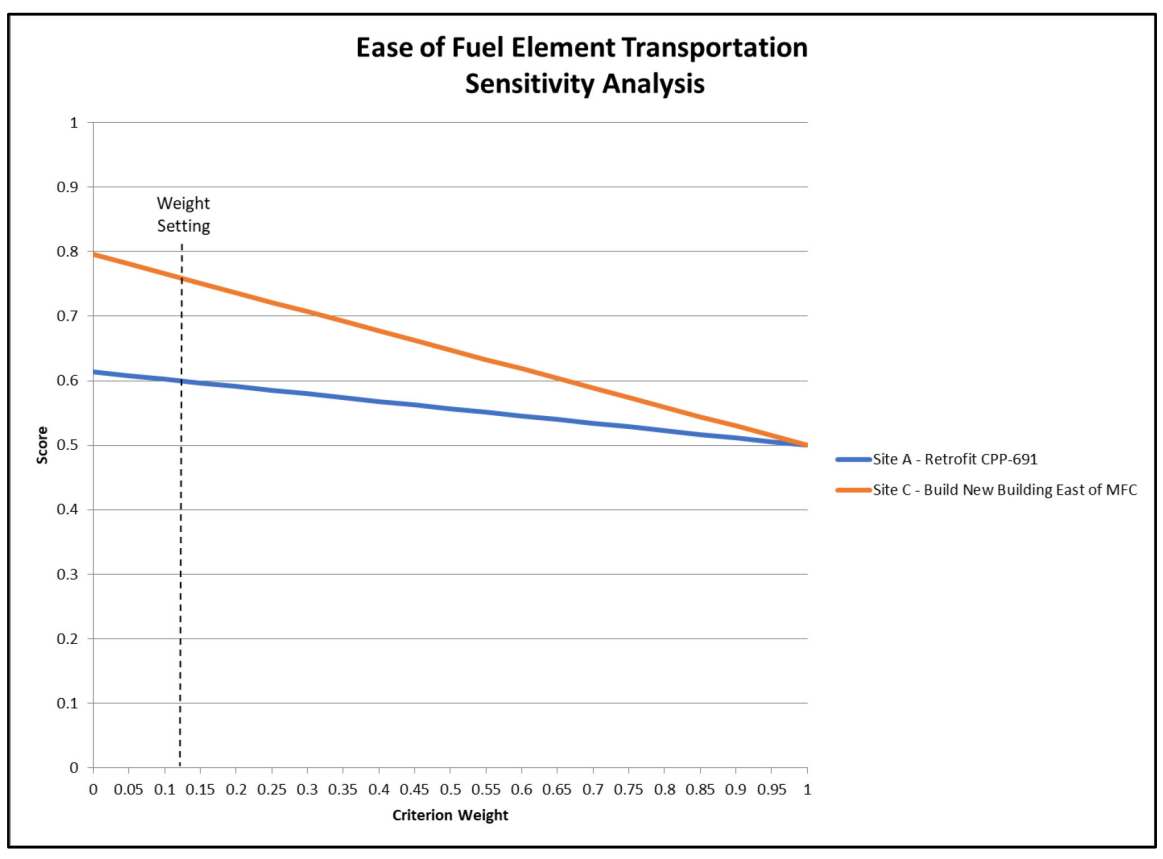

Figure 8. Ease of fuel element transportation criterion weight sensitivity with assigned weight setting. 
TEM-10300-1

$12 / 19 / 2017$

TECHNICAL EVALUATION

Page 26 of 31

Rev. 05

Title: $\quad$ Hybrid - ZIRCEX Process Demonstration Siting Study

$\begin{array}{lllll}\text { TEV No.: } & \text { TEV-3776 } & \text { Rev. No.: } & 0 & \text { Project No.: } 33043 \quad \text { Date: 09/19/2019 }\end{array}$

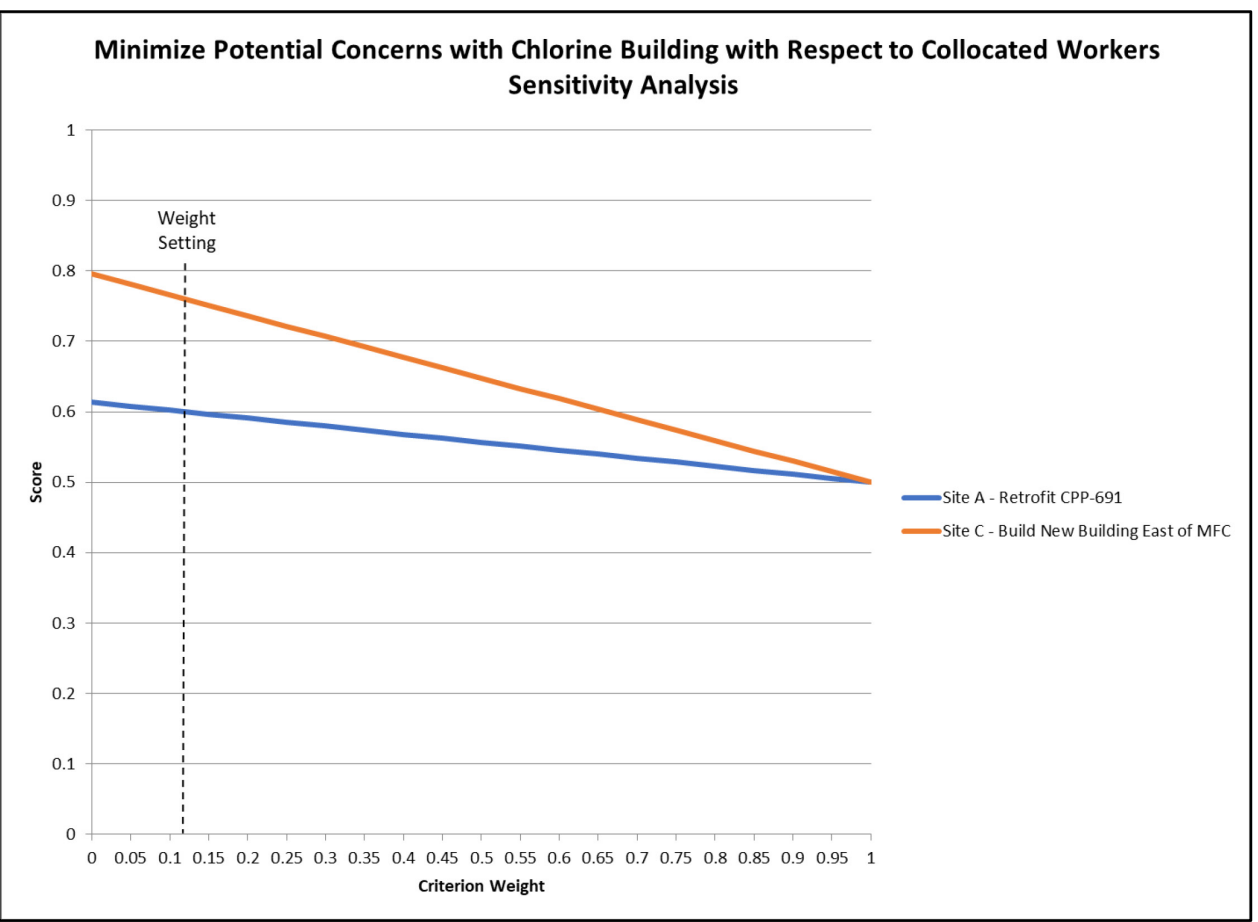

Figure 9. Minimize potential concerns with chlorine building with respect to collocated workers criterion weight sensitivity with assigned weight setting.

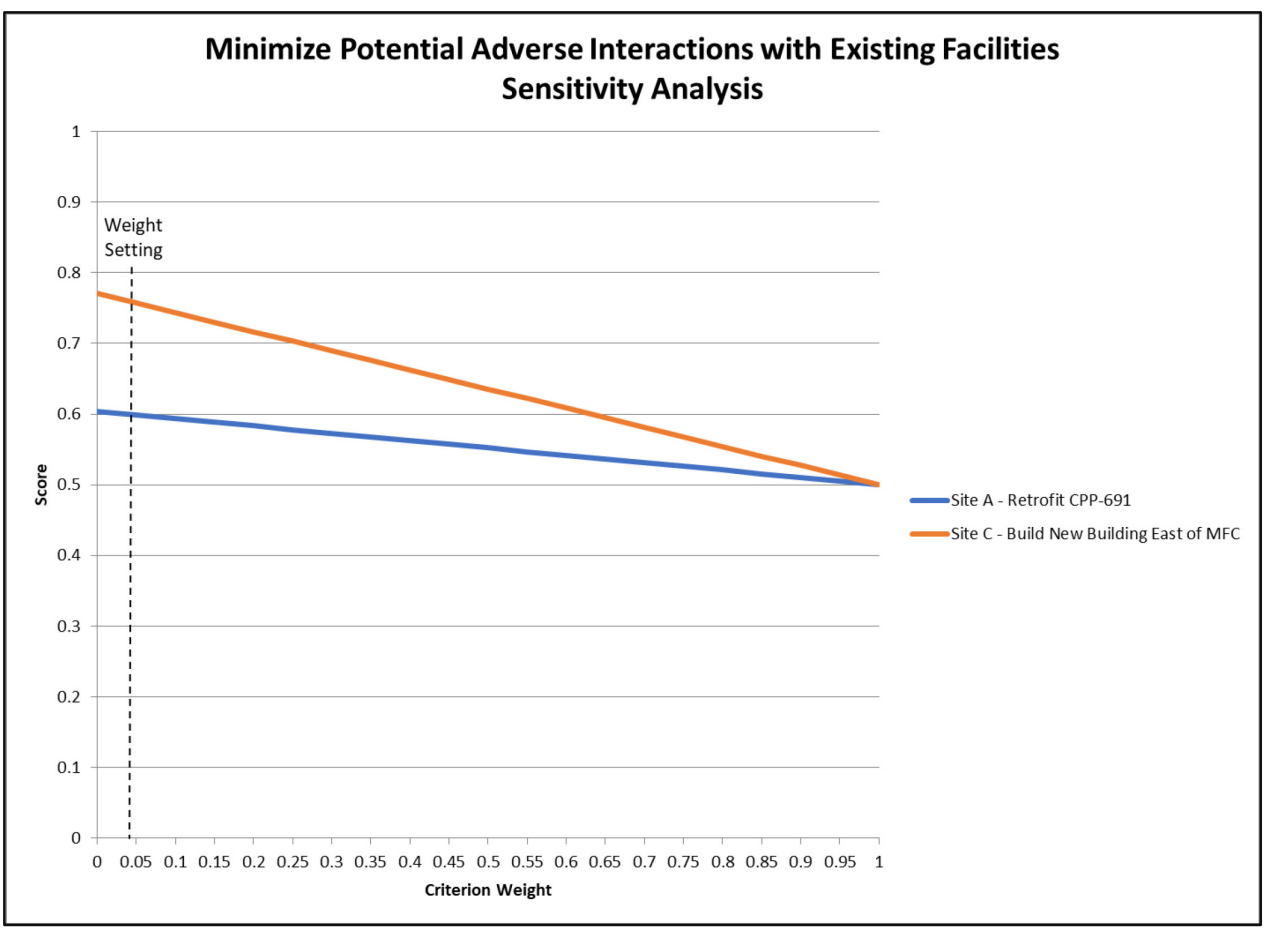

Figure 10. Minimize potential adverse interactions with existing facilities criterion weight sensitivity with assigned weight setting. 
TEM-10300-1

$12 / 19 / 2017$

TECHNICAL EVALUATION

Page 27 of 31

Rev. 05

Title: $\quad$ Hybrid - ZIRCEX Process Demonstration Siting Study

$\begin{array}{lllll}\text { TEV No.: } & \text { TEV-3776 } & \text { Rev. No.: } & 0 & \text { Project No.: } 33043 \quad \text { Date: 09/19/2019 }\end{array}$

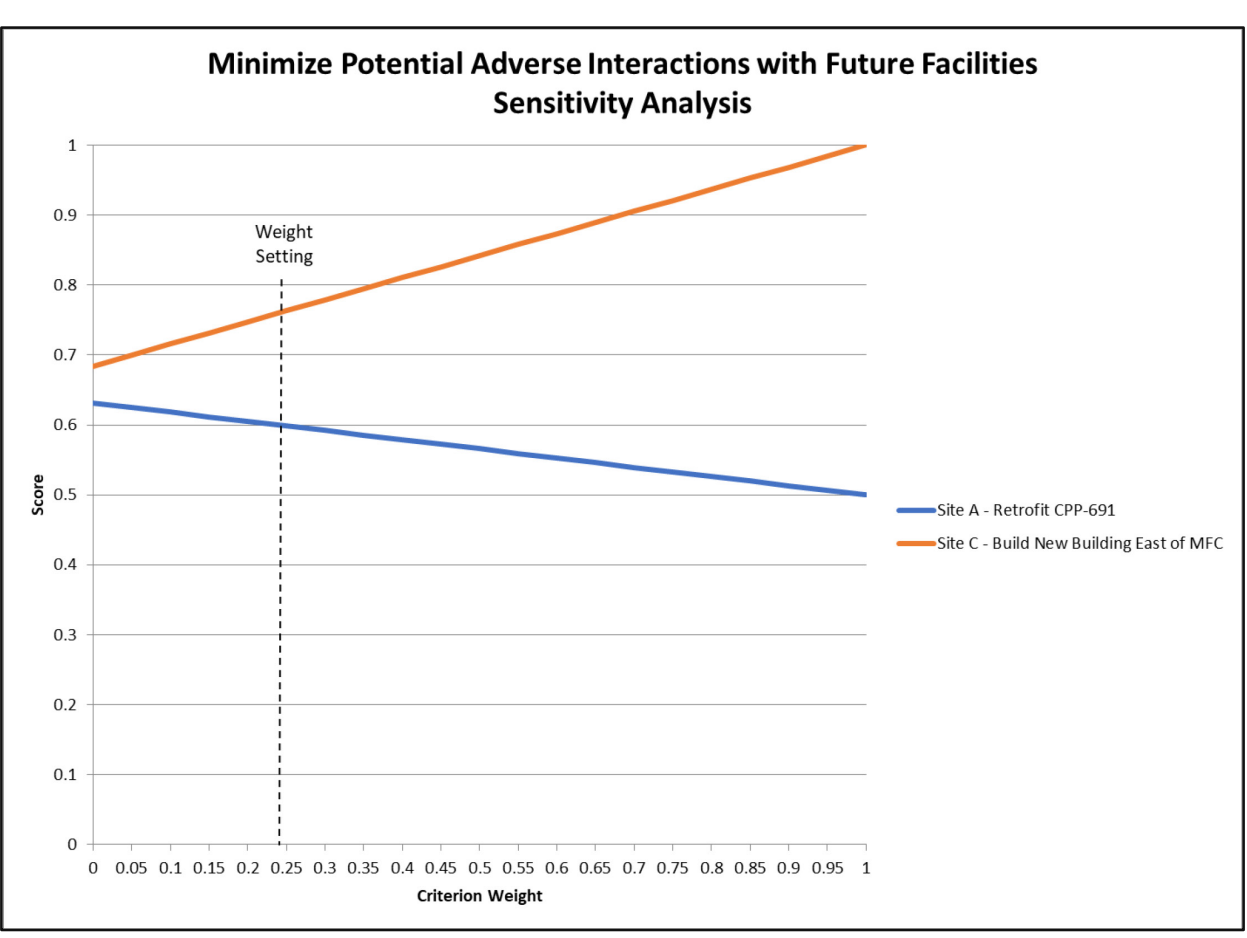

Figure 11. Minimize potential adverse interactions with future facilities criterion weight sensitivity with assigned weight setting.

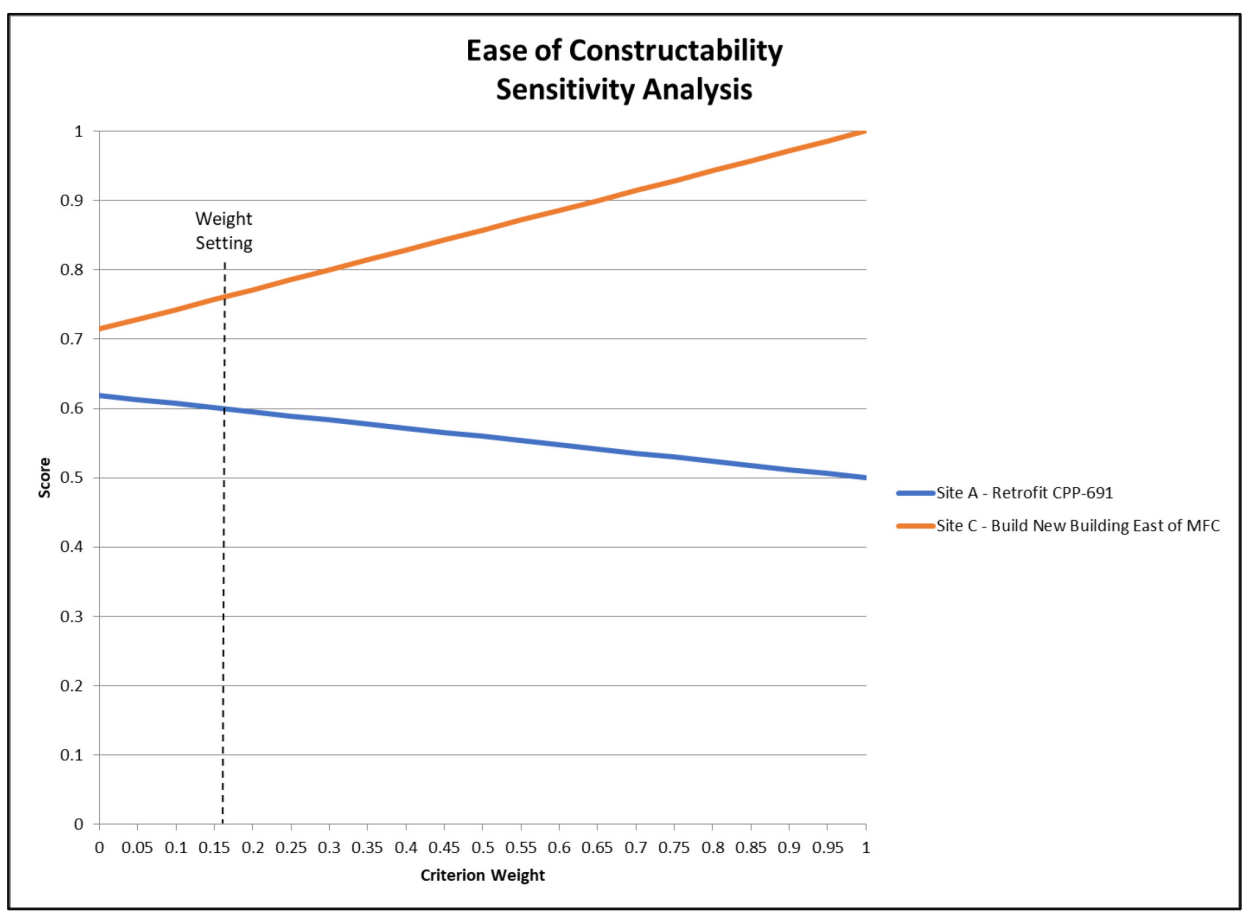

Figure 12. Ease of constructability criterion weight sensitivity with assigned weight setting. 
TEM-10300-1

$12 / 19 / 2017$

TECHNICAL EVALUATION

Page 28 of 31

Rev. 05

Title: $\quad$ Hybrid - ZIRCEX Process Demonstration Siting Study

$\begin{array}{lllll}\text { TEV No.: } & \text { TEV-3776 Rev. No.: } 0 & \text { Project No.: } 33043 \quad \text { Date: } 09 / 19 / 2019\end{array}$

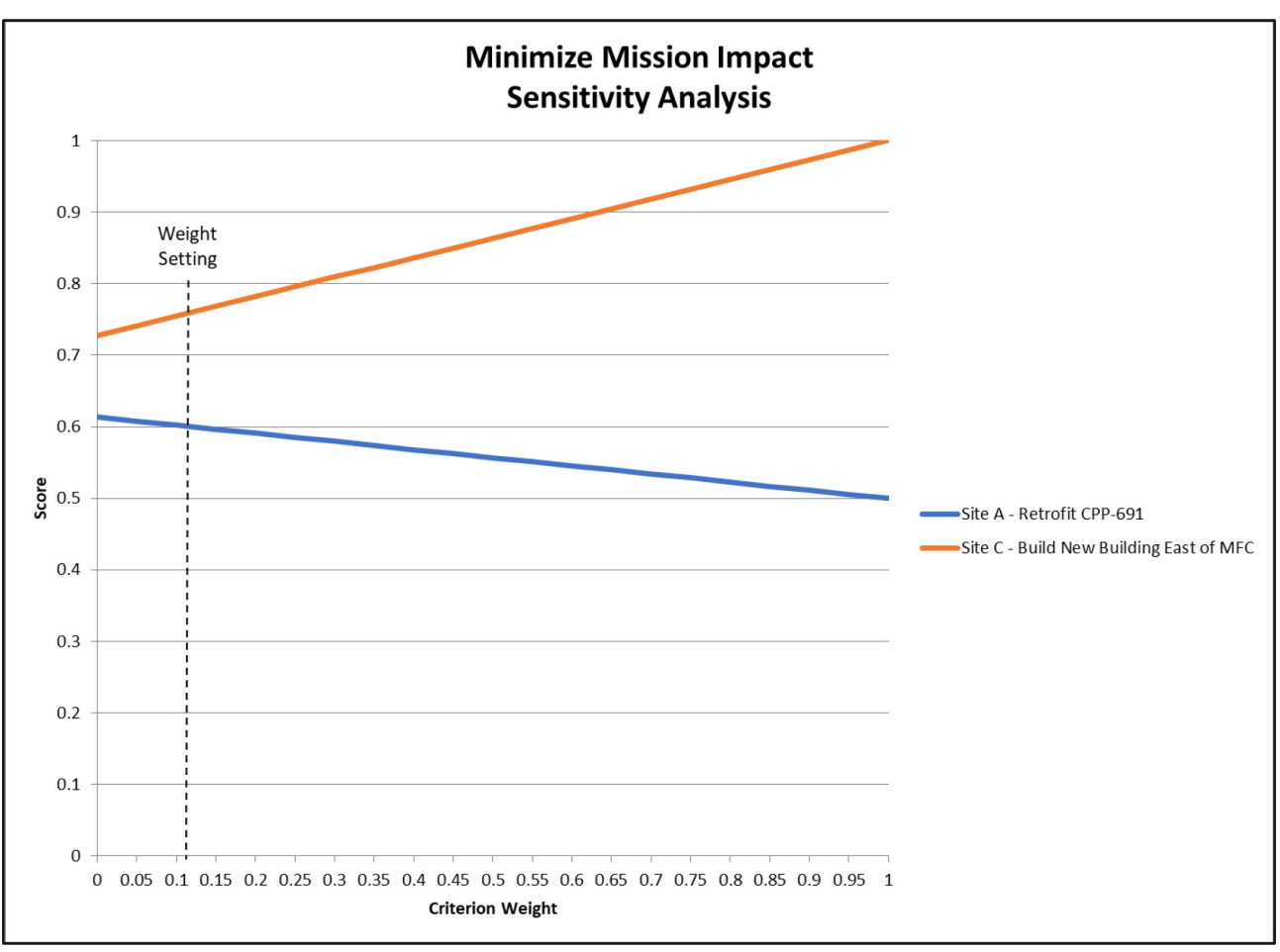

Figure 13. Minimize mission impact criterion weight sensitivity with assigned weight setting.

\subsection{Alternative Scoring Sensitivity}

The alternative scoring sensitivity analysis was performed by parametrically varying by $\pm 20 \%$ each alternative's criteria score (up to a maximum of 1), one-at-a-time holding all other values constant. The overall weighted utility scores were recalculated for each change and charted including error bars to allow comparison of the alternative scores including uncertainty. This type of analysis is a standard output of the QuickCompare ${ }^{\circledR}$ tool.

Figure 14 illustrates the results of the parametric scoring sensitivity analysis. It shows that a $\pm 20 \%$ score uncertainty between Site $A$ and Site $C$ produces no overlaps in the error bars demonstrating that Site C clearly scores higher than Site A in the face of $\pm 20 \%$ scoring uncertainty. 
Rev. 05

Title: $\quad$ Hybrid - ZIRCEX Process Demonstration Siting Study

$\begin{array}{lllll}\text { TEV No.: } & \text { TEV-3776 Rev. No.: } 0 & \text { Project No.: } 33043 \quad \text { Date: } 09 / 19 / 2019\end{array}$

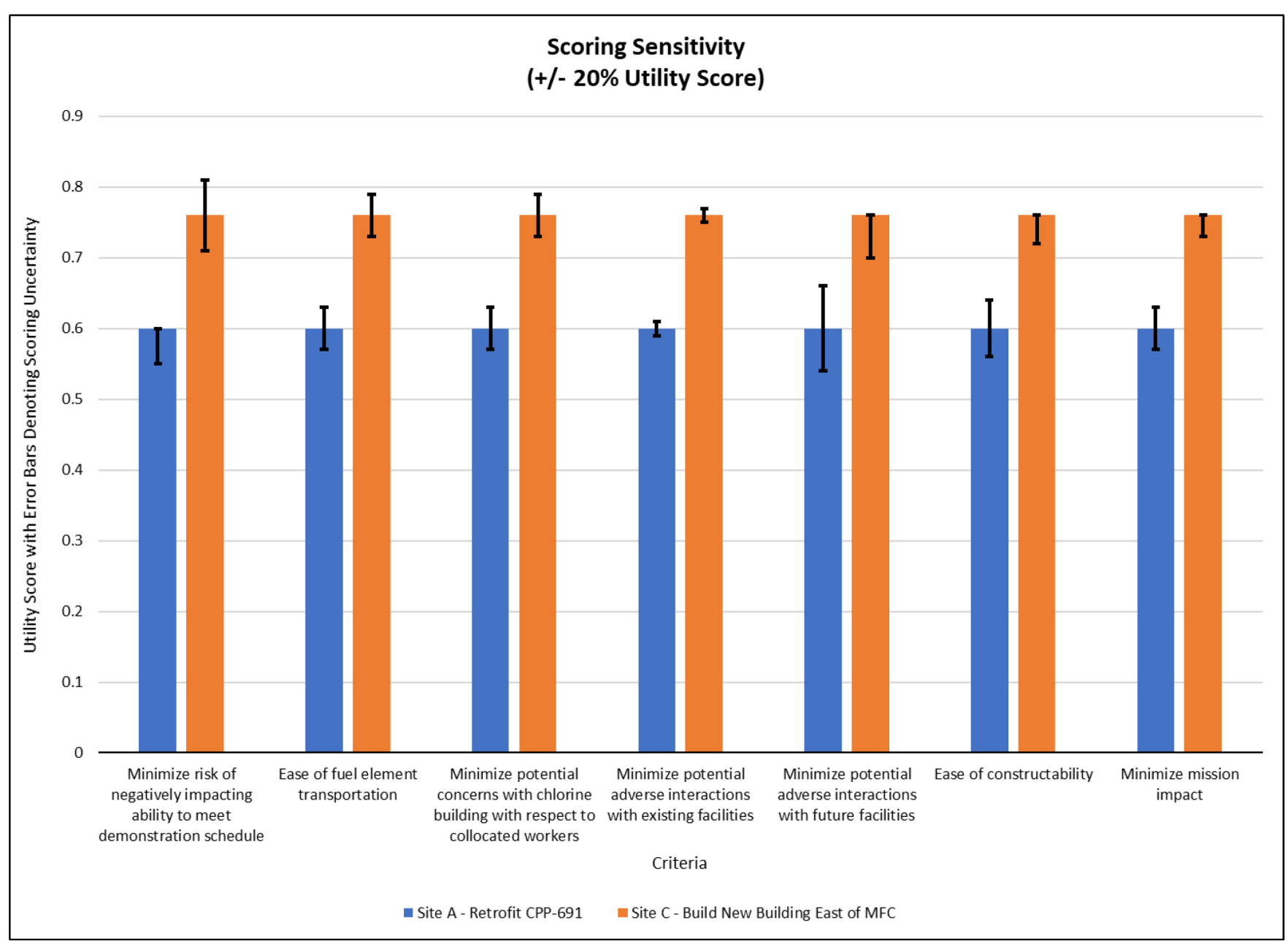

Figure 14. Alternative scoring sensitivity analysis.

\section{COST ESTIMATE COMPARISONS}

INL Cost Estimating was engaged to provide facility modifications/construction costs and 2-3-year demonstration estimates for Site A and Site C. Table 6 provides a summary of the alternative cost estimates. The full cost estimate report including techniques and data sources used in the cost estimate development is available upon request (BEA File 2A34-B).

Table 6. Alternative cost estimates, ranges, and P-80 values.

\begin{tabular}{|l|c|c|c|c|}
\hline \multicolumn{1}{|c|}{ Alternative } & $\begin{array}{c}\text { Point Estimate } \\
(\$ M)\end{array}$ & $\begin{array}{c}\text { Low } \\
(\$ M)\end{array}$ & $\begin{array}{c}\text { High } \\
(\$ M)\end{array}$ & $\begin{array}{c}\text { P-80 } \\
(\$ M)\end{array}$ \\
\hline Site A - Retrofit CPP-691 & $\$ 473.0$ & $\$ 420.3$ & $\$ 634.8$ & $\$ 540.5$ \\
\hline Site C - Build New Building East of MFC & $\$ 448.8$ & $\$ 392.4$ & $\$ 588.6$ & $\$ 506.9$ \\
\hline
\end{tabular}

As can be seen in the table, Site $C$ is estimated to cost less than Site A to construct and complete demonstration. Potential concerns that could adversely impact the costs of selecting either location are the availability of construction resources. 
Rev. 05

Title: $\quad$ Hybrid - ZIRCEX Process Demonstration Siting Study

$\begin{array}{llllll}\text { TEV No.: } & \text { TEV-3776 } & \text { Rev. No.: } & 0 & \text { Project No.: } 33043 \quad \text { Date: } 09 / 19 / 2019\end{array}$

\section{RANK CANDIDATE SITES}

On August 15, 2019, program management decision makers met to discuss the alternatives evaluation results, cost comparisons input, and their INL mission knowledge to reach a consensus on the rank order of the two alternatives. Table 7 identifies the program managers that participated in this activity, their organization, and their role.

Table 7. Scoring participants.

\begin{tabular}{|l|l|}
\hline \multicolumn{1}{|c|}{ Program Management } & \multicolumn{1}{c|}{ Organization/Role } \\
\hline Robert Miklos & MFC Production Facilities/Operations Manager \\
\hline Mike W. Patterson & INL Project Management/HALEU RD\&D Program Execution Manager \\
\hline
\end{tabular}

During this meeting, the project team presented the results of the siting alternatives evaluation, sensitivity analysis, and cost estimates. Comments from the management participants were incorporated into the siting study conclusions and recommendations section.

\section{CONCLUSIONS AND RECOMMENDATIONS}

Based on this analysis, it is recommended that "Site C - Build New Building East of MFC" be selected as the location for the engineering-scale Hybrid - ZIRCEX Process demonstration. SME input plus cost estimating results indicated and management agreed that as a result of the information currently available, Site $\mathrm{C}$ is the best location.

In addition, completion of the alternative scoring sensitivity analysis demonstrated that when challenged with a $\pm 20 \%$ scoring uncertainty, Site C clearly remained the higher scoring alternative.

Also recommended is the inclusion of a preliminary vulnerability assessment during the conceptual design phase to determine the full impact of implementing a new program/facility on adjacent existing and future facilities/programs at MFC.

\section{REFERENCES}

Beebe, C. (corey.beebe@inl.gov), “Telecon Minutes,” L. Guillen (louis.guillen@inl.gov), July 2, 2019.

Behm, C. (chris.behm@in.gov), "HURD 60\% Review Sketches,” A. Conner (alison.conner@inl.gov), June 26, 2019.

Clawson, K.L., J.D. Rich, R.M. Eckman, N.F. Hukari, D. Finn, and B.R. Reese, 2018, “Climatography of the Idaho National Laboratory 4th Edition," NOAA Technical Memorandum OAR ARL-278, NOAA/ Air Resources Laboratory/ Field Research Division, June 2018.

DOE G 420.1-1A, 2012, "Nonreactor Nuclear Safety Design Guide for use with DOE O 420.1C, Facility Safety," U.S. Department of Energy, December 4, 2012.

DOE O 420.1C, Chg. 2, 2018, “Facility Safety,” U.S. Department of Energy, July 26, 2018.

EC INL-18-045, 2018, "Expanded Use of the Multipurpose Haul Road at the Idaho National Laboratory," Regulatory \& Monitoring Services, April 2018. 
Rev. 05

Title: $\quad$ Hybrid - ZIRCEX Process Demonstration Siting Study

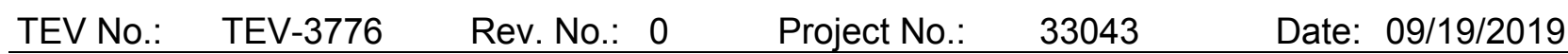

Executive Order 11990, 1977, "Protection of Wetlands,” U.S. Presidential Office, May 24, 1997.

Guillen, L. (louis.guillen@inl.gov), “HURD Facility ROM Square Feet,” M.W. Patterson (mw.patterson@inl.gov) and A. Conner (alison.conner@inl.gov), April 16, 2019.

Harvego, L., J. Connolly, L. Peterson, B. Orr, and B. Starr, 2010, Siting Study for the Remote-Handled Low-Level Waste Disposal Project, INL/EXT-07-12902, Revision 2, October 2010.

Heyer, C. (chris.heyer@inl.gov), “PIDAS,” A. Conner (alison.conner@inl.gov), June 25, 2019.

IAG-578, 2012, “Tenant Use Agreement Between Sitewide Facility Services, Security, and the Haul Road Project,” Rev. 0, INL Site Services, February 2012.

INL, 2019, Natural Phenomena Hazards Design Guidance at INTEC for Development of the HURD Demonstration Project, INL/INT-19-55482, August 2019.

INL, 2019, Natural Phenomena Hazards Design Guidance at MFC for Development of the HURD Demonstration Project, INL/INT-19-55489, August 2019.

Patterson, M.W., P.L. Winston, J. Henley, L. Guillen, E. Gallegos, and J. Bryan, 2019, Study Plan and Final Report: Analysis of Alternatives for Hybrid Uranium Recovery Demonstration Site Selection, INL/LTD-19-52633, Revision 1, January 2019.

TEV-3777, 2019, “Hybrid-ZIRCEX Utility Study,” Rev. 0, Facility Design \& Project Engineering, August 2019.

TEV-3807, 2019, “Site Investigation Study for the HURD Project,” Rev. 0, Facility Design \& Project Engineering, August 2019.

USGS, 2006, Quaternary Fault and Fold Database for the United States, Accessed July 6, 2007, from U.S. Geological Survey web site: http//earthquakes.usgs.gov/regional/qfaults/. 
TEM-10300-1

$12 / 19 / 2017$

TECHNICAL EVALUATION

Page $A 1$ of $A 3$

Rev. 05

Title: $\quad$ Hybrid - ZIRCEX Process Demonstration Siting Study

TEV No.: $\quad$ TEV-3776 Rev. No.: 0

Project No.:

33043

Date: $09 / 19 / 2019$

Appendix A

Supporting Hybrid - ZIRCEX Process 60\% Review Sketches 
TEM-10300-1

$12 / 19 / 2017$

TECHNICAL EVALUATION

Page $A 2$ of $A 3$

Rev. 05

Title: $\quad$ Hybrid - ZIRCEX Process Demonstration Siting Study

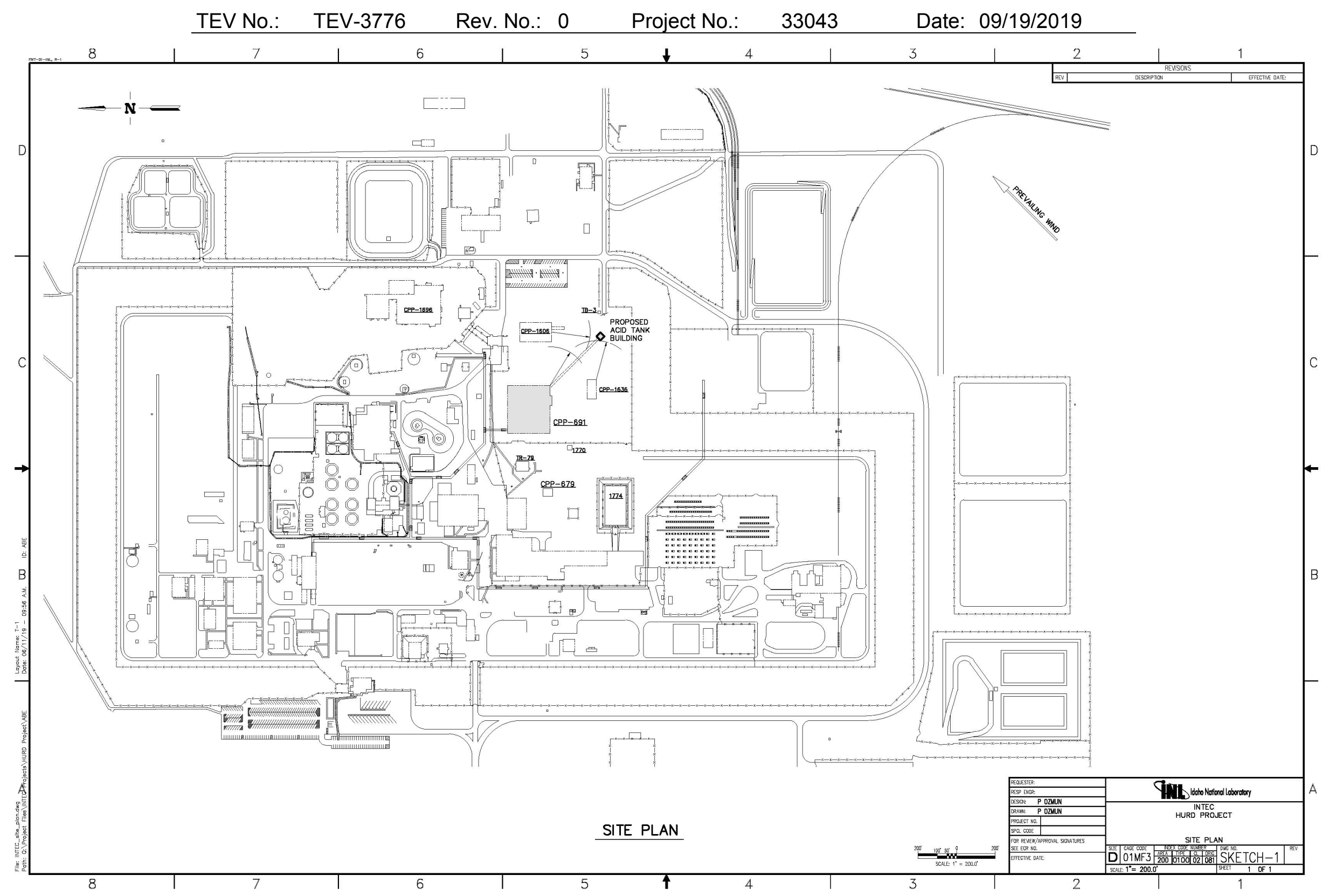


TEM-10300-1

$12 / 19 / 2017$

TECHNICAL EVALUATION

Page $A 3$ of $A 3$

Rev. 05

Title: $\quad$ Hybrid - ZIRCEX Process Demonstration Siting Study

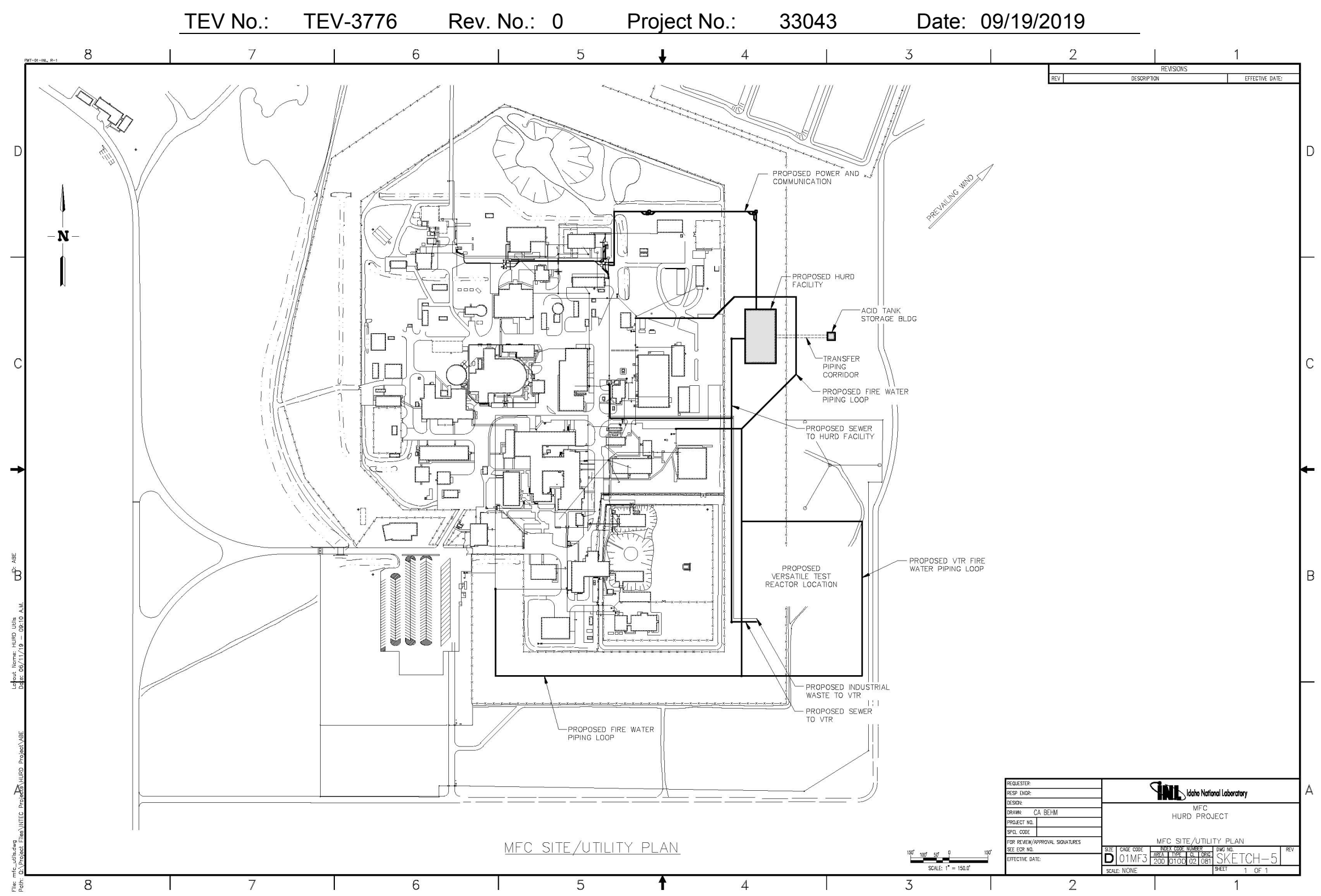


Title:

0

Project No.:

33043

Date:

$09 / 19 / 2019$

\section{Appendix B}

\section{Facilitated Alternatives Analysis}

On June 25, 2019, a facilitated alternatives analysis was conducted to capture SME input on how well the alternative siting locations performed against the "want" criteria. A comparison methodology was used. Using a scale of 10 to 0 , as defined in Table B-1, the team of SMEs assigned a score of " 10 " to the higher performing alternative for each criterion and scored the other alternative in comparison to the high scoring alternative. Table B-1 shows the results of the SME scores.

Table B-1. SME "want" criteria scoring.

\begin{tabular}{|c|c|c|c|c|}
\hline \multirow[b]{3}{*}{ Criteria } & \multicolumn{4}{|c|}{ Alternatives } \\
\hline & \multicolumn{2}{|r|}{ Retrofit CPP-691 } & \multicolumn{2}{|r|}{ Build New at MFC } \\
\hline & Score & Reasoning & Score & Reasoning \\
\hline $\begin{array}{l}\text { Ease of fuel element } \\
\text { transportation }\end{array}$ & 10 & $\begin{array}{l}\text { Comments made regarding transporting fuel: } \\
\text { easier to get fuel in and out at this location, a } \\
\text { route has already been established }\end{array}$ & 5 & $\begin{array}{l}\text { Comments made regarding transporting fuel: } \\
\text { haul road has potential limitations and load } \\
\text { concerns, could be impacted during bad } \\
\text { weather, if haul road unavailable Highway } 20 \\
\text { and DOT requirements imposed }\end{array}$ \\
\hline $\begin{array}{l}\text { Minimize potential concerns } \\
\text { with chlorine building with } \\
\text { respect to collocated } \\
\text { workers (i.e., VTR, } \\
\text { evacuate to } 3.6 \text { miles, etc.) }\end{array}$ & 5 & $\begin{array}{l}\text { Comments made regarding a potential leak: } \\
\text { INTEC is less populated, released plume could } \\
\text { impact CFA, TRA, and NRF (required evacuation } \\
\text { up to } 3.6 \text { miles, Fire Station No. } 1 \text { is the closest if } \\
\text { needed approximately } 3 \text { miles from INTEC, less } \\
\text { of an impact due to security concerns if a total } \\
\text { evacuation is required }\end{array}$ & 5 & $\begin{array}{l}\text { Comments made regarding a potential leak: } \\
\text { proposed site is a greater distance from } \\
\text { collocated buildings, prevailing winds come } \\
\text { from the west and southwest, Highway } 20 \text { is } \\
\text { relatively close, potential fuel storage concern, } \\
\text { quicker response time due to collation of Fire } \\
\text { Station No. } 2 \text { and Emergency Response } \\
\text { personnel at MFC, greater impact if security } \\
\text { personnel evacuation is required }\end{array}$ \\
\hline
\end{tabular}


Rev. 05

Title: $\quad$ Hybrid - ZIRCEX Process Demonstration Siting Study

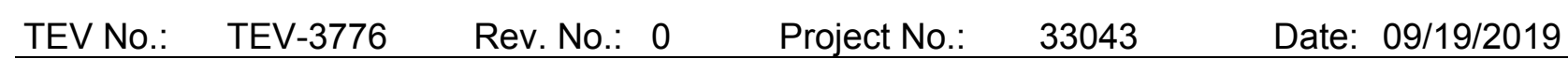

Table B-1. (continued).

\begin{tabular}{|c|c|c|c|c|}
\hline \multirow[b]{3}{*}{ Criteria } & \multicolumn{4}{|c|}{ Alternatives } \\
\hline & \multicolumn{2}{|r|}{ Retrofit CPP-691 } & \multicolumn{2}{|r|}{ Build New at MFC } \\
\hline & Score & Reasoning & Score & Reasoning \\
\hline $\begin{array}{l}\text { Minimize potential adverse } \\
\text { interactions with existing } \\
\text { facilities (i.e., adjacent } \\
\text { buildings, PIDAS, etc.) and } \\
\text { programs }\end{array}$ & 5 & $\begin{array}{l}\text { Comments made in regard to potential adverse } \\
\text { interactions: vulnerability assessment needed for } \\
\text { demonstration. The vulnerability assessment is } \\
\text { needed to identify the following: } \\
\text { - Security infrastructure upgrades that would be } \\
\text { needed to locate the demonstration at either } \\
\text { of the two sites } \\
\text { - Determine if the security posture would be } \\
\text { changed for any potentially adjacent buildings } \\
\text { - Identify potential security impacts imposed by } \\
\text { chlorine storage tank }\end{array}$ & 5 & Same need for vulnerability assessment \\
\hline $\begin{array}{l}\text { Minimize potential adverse } \\
\text { interactions with future } \\
\text { facilities (i.e., adjacent } \\
\text { buildings, PIDAS, etc.) and } \\
\text { programs }\end{array}$ & 5 & Same need for vulnerability assessment & 5 & Same need for vulnerability assessment \\
\hline $\begin{array}{l}\text { Minimize risk of negatively } \\
\text { impacting ability to meet } \\
\text { demonstration schedule } \\
\text { (demo complete } 2023 \text {, run } \\
\text { hot 2025) }\end{array}$ & 5 & $\begin{array}{l}\text { Comments regarding schedule risk: a lot of } \\
\text { unknowns when modifying an existing building, } \\
\text { unknown seismic issues }\end{array}$ & 10 & $\begin{array}{l}\text { Comments regarding schedule risk: least risk, } \\
\text { greenfield schedule has fewer unknowns, } \\
\text { fewer security concerns }\end{array}$ \\
\hline
\end{tabular}


Title: $\quad$ Hybrid - ZIRCEX Process Demonstration Siting Study

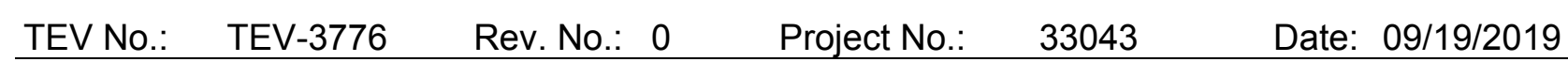

Table B-1. (continued).

\begin{tabular}{|c|c|c|c|c|}
\hline \multirow[b]{3}{*}{ Criteria } & \multicolumn{4}{|c|}{ Alternatives } \\
\hline & \multicolumn{2}{|r|}{ Retrofit CPP-691 } & \multicolumn{2}{|r|}{ Build New at MFC } \\
\hline & Score & Reasoning & Score & Reasoning \\
\hline $\begin{array}{l}\text { Ease of constructability } \\
\text { (moving fences, getting } \\
\text { bidders, getting } \\
\text { construction workers to site, } \\
\text { construction service road, } \\
\text { modify existing structure) }\end{array}$ & 5 & $\begin{array}{l}\text { Comments regarding constructability: no } \\
\text { significant excavation needed, even though it is } \\
\text { an existing building the remodel is not expected } \\
\text { to be as challenging as a typical one due to not a } \\
\text { lot of equipment/utilities that need to be torn out, } \\
\text { concrete is in place, building exists outside of the } \\
\text { fence now, potential seismic mods, inherent } \\
\text { liabilities with modification of existing building }\end{array}$ & 10 & $\begin{array}{l}\text { Comments regarding constructability: known } \\
\text { basalt layer in excavation site, easier to build } \\
\text { new, closer to Idaho Falls so easier to get } \\
\text { construction subcontractors there, outside of } \\
\text { the fence, less impact due to slick roads } \\
\text { during bad weather }\end{array}$ \\
\hline $\begin{array}{l}\text { Minimize mission impact } \\
\text { (EM v. NE, interagency } \\
\text { agreements, competing } \\
\text { missions, mission delay } \\
\text { concerns) }\end{array}$ & 5 & $\begin{array}{l}\text { Comments regarding mission impact: need for } \\
\text { interagency agreement presents potential } \\
\text { challenges, cost sharing implications }\end{array}$ & 10 & $\begin{array}{l}\text { Comments regarding mission impact: all of the } \\
\text { buildings and programs at MFC are in the } \\
\text { same program }\end{array}$ \\
\hline \multicolumn{5}{|c|}{$\begin{array}{l}\text { Scoring Definitions: } \\
10=\text { Meets criteria with minimal to no difficulty } \\
5=\text { Meets criteria with some difficulty } \\
1=\text { High degree of uncertainty as to whether the alternative can meet criteria }\end{array}$} \\
\hline
\end{tabular}


TEM-10300-1

Rev. 05

Title: $\quad$ Hybrid - ZIRCEX Process Demonstration Siting Study

$\begin{array}{llllll}\text { TEV No.: } & \text { TEV-3776 } & \text { Rev. No.: } 0 & \text { Project No.: } 33043 \quad \text { Date: } 09 / 19 / 2019\end{array}$

\section{Hybrid - ZIRCEX Process Siting Alternatives Evaluation}

FOCUS: Operations, Differentiators, Environmental, Safety, Health, Quality of Product, Transportation, Security, Schedule

Meeting Agenda - Tuesday, June 25, 2019

2:00 Introductions

2:05 Demonstration Overview and Siting Alternatives Descriptions

2:20 Discuss and Modify List of Criteria, as needed

3:00 Evaluate Options Against Criteria

3:50 Path Forward

3:55 Adjourn 
TEM-10300-1

$12 / 19 / 2017$

TECHNICAL EVALUATION

Page B5 of B5

Rev. 05

Title: $\quad$ Hybrid - ZIRCEX Process Demonstration Siting Study

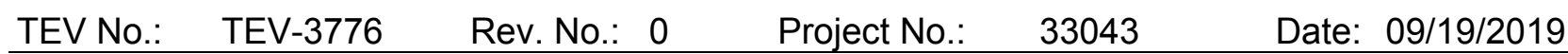

Meeting Participants:

\begin{tabular}{|l|l|}
\hline NAME & ORGANIZATION \\
\hline Stephanie Austad & Facility Design \& Project Engineering \\
\hline Corey Beebe & Systems Analyses \& Engineering \\
\hline Rob Black & Waste Management \\
\hline Troy Bodily & Occupational Safety \& Health - IH \\
\hline Troy Burnett & Fluor \\
\hline Allen Cain & Waste Generator Services - Atkins \\
\hline Michael Cates & Occupational Safety \& Health - Fire Protection \\
\hline Alison Conner & Systems Analyses \& Engineering \\
\hline W. Brooks Cooper & Information Security - Classification Analyst \\
\hline Russ Cottam & Fluor \\
\hline John Espinosa & ES\&H Research and Development - Environmental \\
\hline Howard Forsythe & Fluor \\
\hline Louis Guillen & Facility Design \& Project Engineering \\
\hline Chris Heyer & Physical Security \\
\hline Terry Julius & Cost Estimating \\
\hline John Major & Information Security - Classification Analyst \\
\hline Lawrence McManamon & MFC Occupational Safety \& Health - Safety \\
\hline Bob Miklos & MFC Production Facilities \\
\hline William Newkirk & MFC Occupational Safety \& Health - IH \\
\hline Mike W. Patterson & Project Management \\
\hline Brion Pearson & ES\&H MFC Nuclear Operations - Fire Protection \\
\hline Keith Perry & Project Management \\
\hline Eric Schweinsberg & Waste Management \\
\hline Tim Solle & MFC ES\&S \\
\hline Jimmy Spells & Fluor \\
\hline Cory Stolworthy & Occupational Safety \& Health - Fire Protection \\
\hline Scott Wasley & Cost Estimating \\
\hline &
\end{tabular}


TEM-10300-1

$12 / 19 / 2017$

TECHNICAL EVALUATION

Page $\mathrm{C} 1$ of $\mathrm{C} 8$

Rev. 05

Title: $\quad$ Hybrid - ZIRCEX Process Demonstration Siting Study

TEV No.: $\quad$ TEV-3776 Rev. No.: 0

Project No.:

33043

Date: $09 / 19 / 2019$

Appendix C

Referenced Email Messages 
TEM-10300-1

$12 / 19 / 2017$

TECHNICAL EVALUATION

Page $\mathrm{C} 2$ of $\mathrm{C} 8$

Rev. 05

Hybrid - ZIRCEX Process Demonstration Siting Study

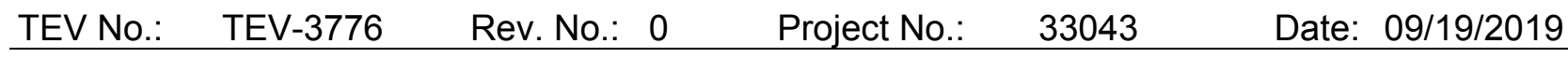

$\begin{array}{ll}\text { From: } & \text { Ghris A. Betm } \\ \text { To: } & \text { olisonM. Comer } \\ \text { Cc: } & \text { Lovis E. Guillen } \\ \text { Subject: } & \text { RE: HURD - 60\% Review Sketches } \\ \text { Date: } & \text { Wiednesday, June 26, 2019 8:58:53 AM } \\ \text { Attachments: } & \text { image002.ipg } \\ & \text { image003.jpg }\end{array}$

Allison,

Placing the HURD facility and tank bldg (with boundaries) in the fencing con figuration in JUB's la yout. I have approximately $290,000 \mathrm{sq} \mathrm{ft}$ ( 6.66 acres).

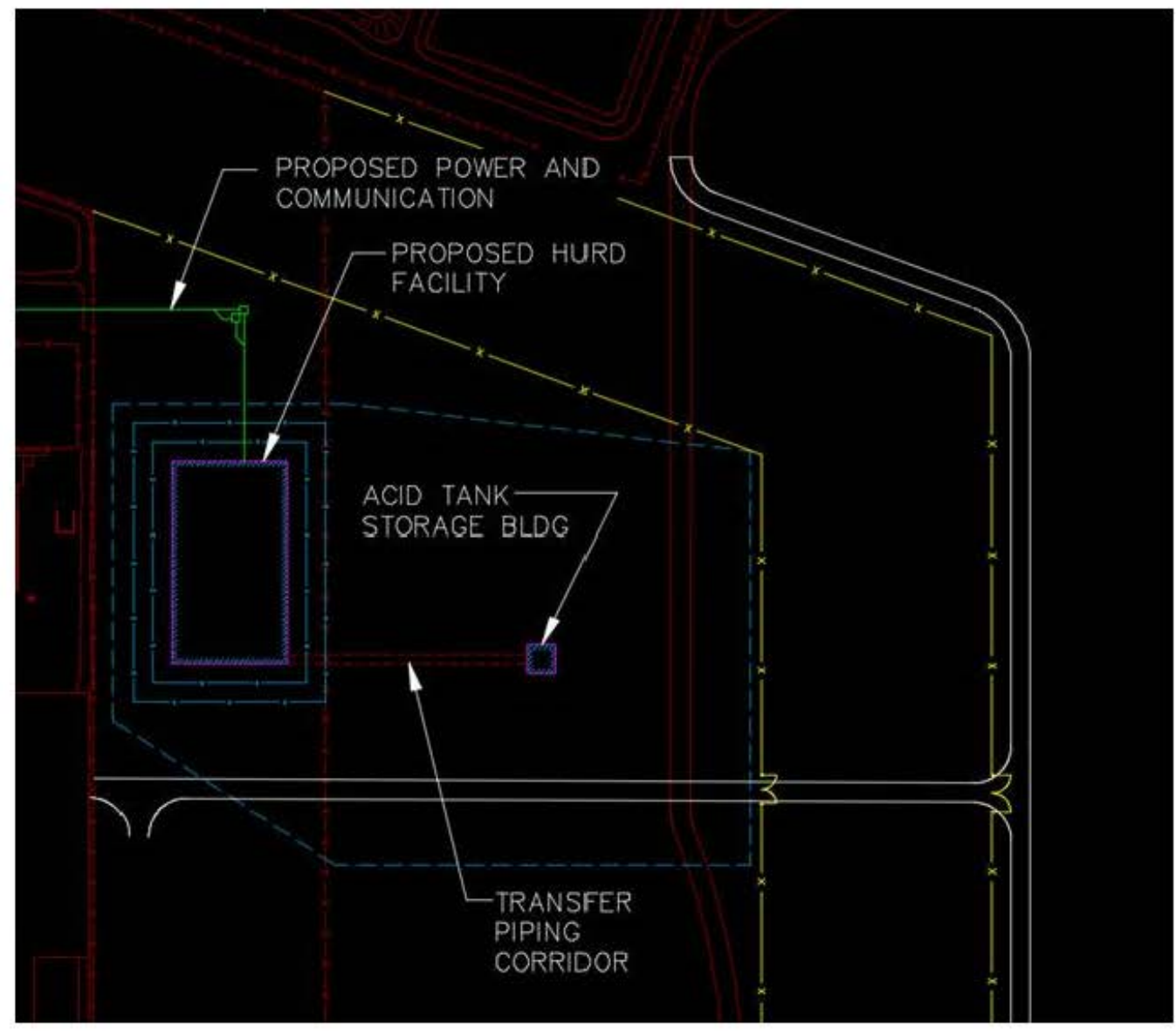

THANKS

CHRISA. BEHM

Idaho National Laboratory, Facility Engineering and Drafting

Office (208) 526-7347 / Mobile (208) 680-5957

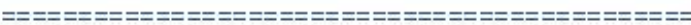

From: Alison M. Conner 
TEM-10300-1

$12 / 19 / 2017$

TECHNICAL EVALUATION

Page C3 of C8

Rev. 05

Title: $\quad$ Hybrid - ZIRCEX Process Demonstration Siting Study

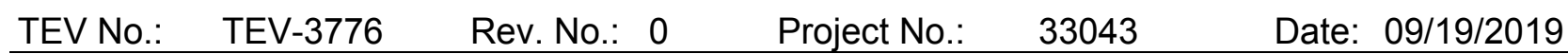

Page 2 of 2

Sent: Tuesday, June 25, 2019 10:58 AM

To: Chris A. Behm <chris.behm@inl.gov>

Cc: Louis E. Guillen <louis.guillen@inl.gov>

Subject: RE: HURD - 60\% Review Sketches

Hi Chris,

Will you please give me the maximum area needed for the new building that includes the area for the tank and a PIDAS? I just confirmed with Chris Heyer in Security that the area needed for a PIDAS is 60 feet from the building ( 20 feet from the building, 20 feet from interior fence to outer fence, and 20 feet clear from the outer fence).

If you have questions, please let me know.

Thanks for your help.

Alison

Alison conner

Systems Analyses \& Engineering

2525 Fremont Ave. - P.O. Box 1625 - Idaho Falls, ID 83415

Office: (208) 526-7799 - Email: Alison.Conner@inl.gov

cid:300237a4-360d-435c-90e7-002b180ba20c

2.

From: Chris A. Behm <chris.behm@inl.gov>

Sent: Tuesday, June 11, 2019 2:20 PM

To: Louis E. Guillen <louis.guillen@in..gov>; Alison M. Conner <alison.conner@inl.gov>; Phillip M. Ozmun <phillip.ozmun@inl.gov>

Subject: HURD - 60\% Review Sketches

See attched

THANKS

CHRIS A. BEHM

Idaho National Laboratory, Facility Engineering and Drafting

Office (208) 526-7347 / Mobile (208) 680-5957

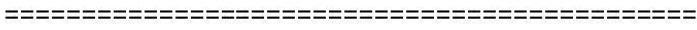


TEM-10300-1

$12 / 19 / 2017$

TECHNICAL EVALUATION

Page C4 of C8

Rev. 05

Title: $\quad$ Hybrid - ZIRCEX Process Demonstration Siting Study

$\begin{array}{llllll}\text { TEV No.: } & \text { TEV-3776 } & \text { Rev. No.: } & 0 & \text { Project No.: } & 33043 \quad \text { Date: } 09 / 19 / 2019\end{array}$

Page 1 of 2

\begin{tabular}{ll} 
From: & Corey L. Beebe \\
To: & LouisE. Guillen \\
Cc: & Keith J. Perry; MW ". Patterson; Emily K. Gallegos; Alison M. Conner \\
Subject: & FW: Telecon Minutes \\
Date: & Tuesday, July 2, 2019 1:41:23 PM \\
Attachments: & imaae001.Dng \\
\hline
\end{tabular}

All,

See minutes below from telecon with Chris Heyer regarding siting and chemical storage tanks. This answers 2 out of the 3 bulleted action items I had from the Siting meeting. I'm still working the upgrades that would be needed at the 2 proposed locations.

Thanks,

Corey

\section{Corey Beebe}

Systems Engineering

Idaho National Laboratory

Office: (208) 526-9879

Cell: (208) 351-1201

Email: corey.beebe@inl.gov

SIPR: corey.beebe@idaho.doe.sgov.gov

From: Chris E. Heyer <chris.heyer@inl.gov>

Sent: Tuesday, July 2, 2019 11:13 AM

To: Corey L. Beebe <corey.beebe@inl.gov>

Cc: Eric S.Willis <eric.willis@inl.gov>; PT. Pettingill<p.pettingill@inl.gov>

Subject: Re: Telecon Minutes

Corey,

Accurate as written. FYI we generally call the area between the two fences the isolation zone.

Thank you,

Chris Heyer

Lead Physical Security Officer

B27-603, Room 105

Phone \& Text (208) 360-4048

From: Corey L. Beebe

Sent: Tuesday, July 2, 2019 9:53:01 AM

To: Chris E. Heyer

Subject: Telecon Minutes

Chris,

Below are the minutes from our telecon. Please let me know if you have any corrections or additions.

Telecon with Chris Heyer

2 July 2019 
TEM-10300-1

$12 / 19 / 2017$

TECHNICAL EVALUATION

Page C5 of C8

Rev. 05

Title: $\quad$ Hybrid - ZIRCEX Process Demonstration Siting Study

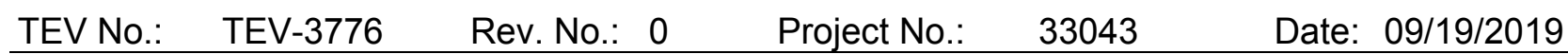

Page 2 of 2

With regard to chemical storage tanks within the Protection Area (PA):

- The tanks are better protected inside the PA

- Vendors will need to be escorted inside the PA to fill and maintain tanks

- The first fence is $20 \mathrm{ft}$ from an y structure

- The distance of the tanks from the facility is not a security function and is TBD

- The PIDAS double fence is $20 \mathrm{ft}$ between the fences

- There is a $20 \mathrm{ft}$ isolation zone beyond the second fence

- Minimum of $60 \mathrm{ft}$ from structure to the edge of the isolation zone

With regard to the Demonstration Facility impacting existing programs:

- The location of the facility should not be a discriminating siting factor, whenever you stand up a new facility, an assessment will be conducted to determine what detection systems or SPO are needed to comply with regulations.

- The impact is time and money for security compliance not adverse effect to other programs

- Compliance to security regulations is met by detection and personnel, not distance from other facilities as long as you meet minimum isolation distances

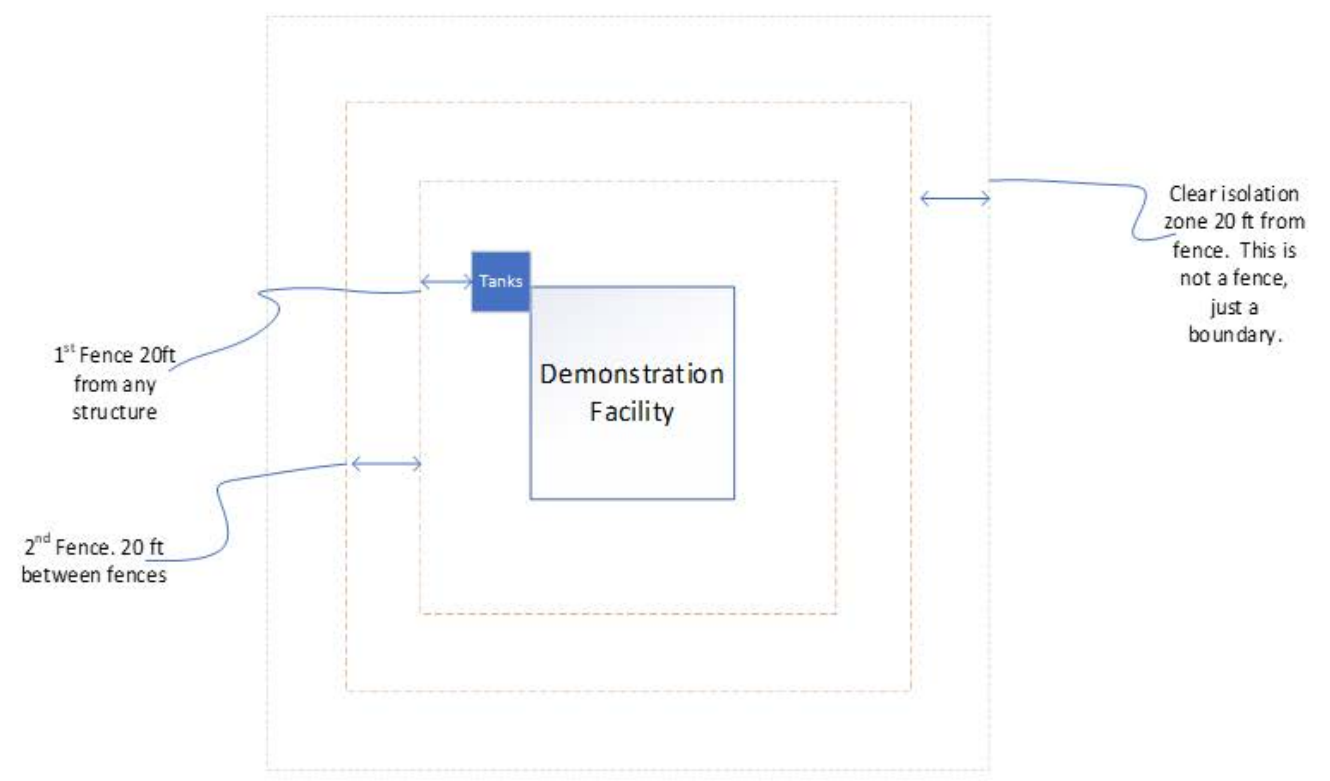

Thanks,

Corey

Corey Beebe

Systems Engineering

Idaho National Laboratory

office: (208) 526-9879

Cell: (208) 351-1201

Email: corey, beeberinl.gov

SIPR: corey,beeber(đidaho,doe,sgoy,gov 
TEM-10300-1

$12 / 19 / 2017$

TECHNICAL EVALUATION

Page $\mathrm{C} 6$ of $\mathrm{C} 8$

Rev. 05

Title: $\quad$ Hybrid - ZIRCEX Process Demonstration Siting Study

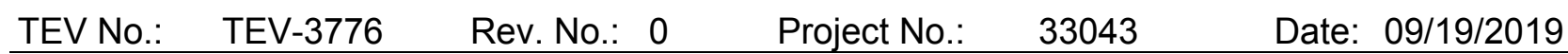

Page 1 of 2

$\begin{array}{ll}\text { From: } & \text { Ghris E. Hever } \\ \text { To: } & \text { OlisonM. Comer } \\ \text { Subject: } & \text { Re: PIDAS } \\ \text { Date: } & \text { Tuesday, June 25, 20199:27:29 AM }\end{array}$

Eric is correct. No structure within 20 feet of the PIDAS fence line and the PIDAS itself is 20 feet between exterior and in terior fence line.

Additionally the fence at a minimum must be 7 fee in height including the razor wire at the top. be of 11 gauge wire mesh with openings no greater than $Z$ inches. The fence must extend to within $Z$ inches of hard ground.

Thank you,

Chris Hever

Lead Physical Security officer

B27-603, Room 105

Phone \& Text (208) 360-4048

From: Alison M. Conner

Sent: Tuesday, June 25, 2019 8:03:43 AM

To: Chris E. Heyer

subject: FW: PIDAS

Chris,

Below is a note that Eric Willis sent to the HURD Project Manager, Mike Patterson, identifying the area required for a PIDAS. Will you please confirm that this is the required area? I'm trying to confirm the minimum square footage for the siting study.

Thanks for your help.

Alison

Alíson comner

Systems Analyses \& Engineering

2525 frem ont Ave. - P.O. Box 1625 - Idaho F alls, ID 83415

Office: (208) 526-7799 - Email: Alison.Conner@ind.goy

Idaho National Laboratory

From: MW'.Patterson<mw.putterson@irl.Bow>

Sent: Wednesday, December 19,2018 8:27 AM 
TEM-10300-1

$12 / 19 / 2017$

TECHNICAL EVALUATION

Page $\mathrm{C} 7$ of $\mathrm{C} 8$

Rev. 05

Title: $\quad$ Hybrid - ZIRCEX Process Demonstration Siting Study

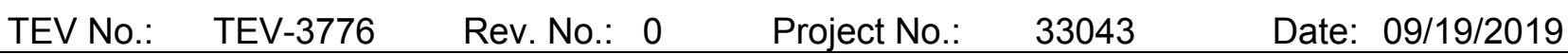

Page 2 of 2

To: Louis E. Guillen<louis.guillen@inl.gov>; Jeffrey D. Bryan<jeffrey.bryan@inl.gov>; Jody L. Henley<jody.henley@inl.gov>; Scott N. Wasley<scott.wasley@inl.gov>; Gary I. Dansie $<$ gary.dansie@inl.gov>

Cc: Eric S. Willis <eric.willis@inl.gov>

Subject: FW: PIDAS

Folks - I think this means the fence has to go around the CSSFs to the east and southeast, which by my quick calculation means about 1600 feet of fence. Also, the underground tanks to the west would need to be filled in with grout (some already done) and more importantly, the tank farm closure has to finish by about 2023 so the tanks can be grouted in. That's a risk anybody betting on IWTU?

Thanks for the info Eric.

Mike

From: Eric S. Willis <eric.willis@inl.gov>

Sent: Tuesday, December 18, 2018 4:57 PM

To: MW'. Patterson <mw.patterson@inl.gov>

Subject: PIDAS

Mike,

The total area you need is 60 feet from the building for a PIDAS. 20 feet from the building, 20 feet from interior fence to outer fence, and 20 feet clear from the outer fence.

I have included my sources from the DOE order. Let me know if you have any questions.

DOE O 473.3A Attachment 3, Section A 3-23-2016 3-31

Fences installed after the effective date of this Order must be no closer than 20 feet ( 6 meters) from the building or S\&S interest being protected.

Perimeter Intrusion Detection and Assessment System. The PIDAS surrounding the protected area must be monitored in a continuously manned central alarm station and a secondary alarm station. PIDAS must be:

provided with an isolation zone at least 20 feet ( 6 meters) wide and clear of fabricated or natural objects that would interfere with operation of detection systems or the effectiveness of the assessment; and

free of wires, piping, poles, and similar objects that could be used to assist an intruder traversing the isolation zone or that could assist in the undetected ingress or egress of an 
TEM-10300-1

$12 / 19 / 2017$

TECHNICAL EVALUATION

Page C8 of C8

Rev. 05

Title: $\quad$ Hybrid - ZIRCEX Process Demonstration Siting Study

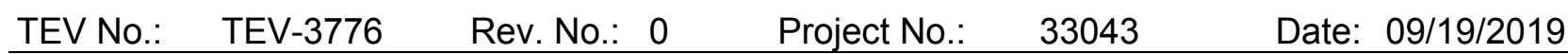

Page 1 of 1

$\begin{array}{ll}\text { From: } & \text { Louis E. Guillen } \\ \text { To: } & \text { MW ". Patterson; Alison M. Conner } \\ \text { Cc: } & \text { Stephanie L. Austad; Keith J. Perry } \\ \text { Subject: } & \text { RE: HURD Facility ROM Sq. Todd } \\ \text { Date: } & \text { Tuesday, April 16, 2019 1:40:30 PM }\end{array}$

Alison, I will send you a new estimate tomorrow based on $1 / 4$ reduction of pencil tank storage. Note, all other process equipment remains "full size" so that space will not be adjusted.

$\lg$

From: MW'. Patterson

Sent: Tuesday, April 16, 2019 1:38 PM

To: Louis E. Guillen <lou is.guillen@inl.gov>; Alison M. Conner<alison.conner@inl.gov>

Cc: Stephanie L. Austad <stephanie.austad@inl.gov>; Keith J. Perry<Keith.Perry@inl.gov>; Terry A. Todd <terry.todd@inl.gov>

Subject: RE: HURD Facility ROM Square Feet

Louis -

We've talked about reducing the amount of inter-process storage - basically fewer pencil tanks. We chose a full year's storage because Jeff pushed for best operational efficiency. Since then, I've heard lots of discussion about reducing the storage and throughput because this is just a demonstration.

Would 3 months of tank storage be adequate for a demonstration (I think yes) and should we change the assumption for capacity?

Mike

From: Louis E. Guillen <louis.guillen@inl.gov>

Sent: Tuesday, April 16, 2019 1:21 PM

To: Alison M. Conner <alison.conner@inl.gov>

Cc: Stephanie L. Austad <stephanie.austad@inl.gov>; MW'. Patterson<mw.patterson@inl.gov>

Subject: HURD Facility ROM Square Feet

The total building was never sized as only hot cell space was investigated. But, the following are estimates: Hot Cells: 8700 sq. ft. (not accounting for wall thickness), Operating Corridor 800 sq. ft. , Access Corridor 800 sq. ft., Maintenance Corridor 800 sq. ft. (manipulator cells). Sample Room 100 sq. ft. Cask Handling: 2,000 sq. ft. Electrical Room 1,000 sq. ft. Fan Room: 1,000 sq. ft. Ancillary space 7000 sf. ft. (i.e. wall thickness, restrooms, etc). So at a ROM $=25,000$ Sq. Ft.

This also does not include outside security fencing or vehicle maneuvering. 